\title{
Large mammal burrows in late Miocene calcic paleosols from central Argentina: palaeoenvironment, taphonomy and producers
}

\author{
María Cristina Cardonatto ${ }^{\text {Corresp., }}{ }^{1}$, Ricardo Néstor Melchor ${ }^{2}$ \\ 1 Departamento de Geología, Facultad de Ciencias Exactas y Naturales, Universidad Nacional de La Pampa, Santa Rosa, La Pampa, Argentina \\ 2 Instituto de Ciencias de la Tierra y Ambientales de La Pampa, Universidad Nacional de La Pampa and Consejo Nacional de Investigaciones Científicas y \\ Técnicas, Santa Rosa, La Pampa, Argentina \\ Corresponding Author: María Cristina Cardonatto \\ Email address: mccardonatto@exactas.unlpam.edu.ar
}

Large cylindrical sediment-filled structures interpreted as mammal burrows occur within the loess-paleosol sequence of the late Miocene Cerro Azul Formation of central Argentina. A total of 115 burrow fills from three localities were measured. They are typically shallowly dipping, subcylindrical, unbranched structures with rounded ends and lacking enlargements. The horizontal diameter of the burrows range between 0.15 and $1.50 \mathrm{~m}$, with most of the burrows in the interval of 0.39 to $0.98 \mathrm{~m}$. Geometric morphometric analysis of transverse cross-sections support their distinct subcircular and elliptical (horizontally flattened) shapes. Burrow fills are typically laminated in the lower part and massive in the upper part. The laminated intervals reflect pulses of flowing water entering the abandoned burrow during moderate rains, whereas massive intervals reflect mass flow input of dense sediment-water mixtures during heavy rains that produced sheet floods. Approximately $1 \%$ of the burrows contained fragmentary, disarticulated and weathered mammal bones that were introduced in the open burrow by currents along with other sedimentary particles. Analysis of the tetrapod burrow fossil record suggests that Miocene burrows, including those studied herein, reflect a remarkable increase in the average size of the fossorial fauna. We conclude that large late Miocene mammals dug burrows essentially as a shelter against environmental extremes and to escape predation. The simple architecture of the burrows suggests that the producers essentially foraged aboveground. Several mammal groups acquired fossorial habits in response to cold and seasonally dry climatic conditions that prevailed during the late Miocene in southern South America. The considerable range of horizontal diameters of the studied burrows can be attributed to a variety of producers, including dasypodids, the notoungulate Paedotherium minor, Glyptodontidae and Proscelidodon sp. 


\section{Large mammal burrows in late Miocene calcic paleosols from central}

\section{Argentina: palaeoenvironment, taphonomy and producers}

3 María Cristina Cardonatto ${ }^{1}$, Ricardo Néstor Melchor ${ }^{1,2}$

$4 \quad{ }^{1}$ Universidad Nacional de La Pampa, Departamento de Geología, Facultad de Ciencias Exactas

5 y Naturales, Santa Rosa, La Pampa, Argentina.Email: mccardonatto@exactas.unlpam.edu.ar

$6 \quad{ }^{2}$ Universidad Nacional de La Pampa and Consejo Nacional de Investigaciones Cientificas y

7 Técnicas, Instituto de Ciencias de la Tierra y Ambientales de La Pampa, Santa Rosa, La Pampa,

8 Argentina.

9

10 Corresponding autor:

11 María Cristina Cardonatto $^{1}$ 


\section{Abstract}

Large cylindrical sediment-filled structures interpreted as mammal burrows occur within the loess-paleosol sequence of the late Miocene Cerro Azul Formation of central Argentina. A total of 115 burrow fills from three localities were measured. They are typically shallowly dipping, subcylindrical, unbranched structures with rounded ends and lacking enlargements. The horizontal diameter of the burrows range between 0.15 and 1.50 $\mathrm{m}$, with most of the burrows in the interval of 0.39 to $0.98 \mathrm{~m}$. Geometric morphometric analysis of transverse cross-sections support their distinct subcircular and elliptical (horizontally flattened) shapes. Burrow fills are typically laminated in the lower part and massive in the upper part. The laminated intervals reflect pulses of flowing water entering the abandoned burrow during moderate rains, whereas massive intervals reflect mass flow input of dense sediment-water mixtures during heavy rains that produced sheet floods. Approximately $1 \%$ of the burrows contained fragmentary, disarticulated and weathered mammal bones that were introduced in the open burrow by currents along with other sedimentary particles. Analysis of the tetrapod burrow fossil record suggests that Miocene burrows, including those studied herein, reflect a remarkable increase in the average size of the fossorial fauna. We conclude that large late Miocene mammals dug burrows essentially as a shelter against environmental extremes and to escape predation. The simple architecture of the burrows suggests that the producers essentially foraged aboveground. Several mammal groups acquired fossorial habits in response to cold and seasonally dry climatic conditions that prevailed during the late Miocene in southern South America. The considerable range of horizontal diameters of the studied burrows can be attributed to a variety of producers, including dasypodids, the notoungulate Paedotherium minor, Glyptodontidae and Proscelidodon sp.

\section{Introduction}

Fossil vertebrate burrows are relatively common biogenic structures and the oldest convincing evidence of tetrapod burrows are Early Permian (Asselian-Artinskian) lysophorid amphibian burrows from Kansas, USA (Hembree, Martin \& Hasiotis, 2004). Most pre-Cretaceous tetrapod burrows have been attributed to therapsids, in part on the basis of the finding of articulated 
42 skeletons in a few Late Permian-Early Triassic burrows (Smith 1987; Groenewald, Welman \&

43 MacEachern, 2001; Damiani et al., 2003; Modesto \& Botha-Brink 2010). A common

44 architecture for Permian to Jurassic tetrapod burrows is a shallowly inclined ramp with a rounded

45 and not enlarged end, of reduced horizontal diameter (Fig. 1), with discrete scratch marks,

46 always showing a horizontally flattened elliptical cross-section, and commonly with a bilobed

47 bottom (e.g., Damiani et al., 2003; Sidor et al., 2008; Riese, Hasiotis \& Odier, 2011; Liu \& Li

48 2013; Melchor \& Loope 2016; Krummeck \& Bordy, 2017). Most of Jurassic tetrapod burrows

49 occur in eolian sequences including the oldest subhorizontal burrow systems that have been

50 assigned to primitive mammals from the Early Jurassic Navajo Sandstone of USA (Riese,

51 Hasiotis \& Odier, 2011) (Fig. 1). In contrast, there is a dearth of reports of Cretaceous tetrapod

52 burrows which could possibly be due to the more equable climates that existed for most of this

53 period. An exceptional occurrence for the Late Cretaceous is the unique dinosaur burrow

54 containing an adult and two juvenile remains of ornithopods, further suggesting denning

55 behavior and parental care (Varricchio, Martin \& Katsura, 2007).

Most Cenozoic tetrapod burrows have been attributed to mammals, mainly to Rodentia

57 and Xenarthra (e.g., Voorhies, 1975; Martin \& Bennett 1977; Benton, 1988; Gobetz \& Martin

2006), whereas a few examples are related to Carnivora (e.g., Hunt, Xiang-Xu \& Kaufman,

1983; Hembree \& Hasiotis 2008). The record of Paleogene tetrapod burrows is meager and may

also be linked to dominantly benign climate conditions (Fig. 1). The Miocene record of tetrapod

61 burrows is more varied and abundant, with a diversification of the architectural patterns and

62 behavioral strategies that, commonly, appeared under stressed volcaniclastic and eolian

63 environments. The early Miocene volcaniclastic floodplains of Nebraska, USA, witnessed the

64 appearance of 1) the celebrated vertical helical burrows ending in a ramp and terminal chamber 
65 named Daimonelix (e.g., Barbour, 1892; Martin \& Bennett, 1977), as well as 2) smaller, complex

66 subhorizontal rodent burrow systems with terminal chambers and subcircular cross-section

67 (Gobetz \& Martin, 2006), and 3) the first carnivore den (Hunt, Xiang-Xu \& Kaufman, 1983;

68 Hunt 1990). Also in the early Miocene, the coastal dunes of Germany preserved the oldest fossil

69 food cache (Gee et al., 2003). The main tetrapod burrowing innovation during the middle

70 Miocene is represented by cylindrical, subhorizontal, unbranched tunnels with a meniscate

71 backfill interpreted as foraging tunnels of small Dasypodidae from southern South America

72 (Melchor et al., 2012; 2016). Pliocene burrows are small (horizontal diameter less than $250 \mathrm{~mm}$ )

73 and those from the Atlantic coast of the Buenos Aires province, Argentina have received a

74 considerable attention, because they are common and a significant number of the burrows

75 contains bone remains (e.g., Genise, 1989; Quintana, 1992; Fernández, Vassallo \& Zárate, 2000;

76 Elissamburu, Dondas \& De Santis, 2011). These are subcircular burrows assigned to rodents and

77 notoungulates. The Pleistocene megafauna of South America is also reflected in the burrow trace

78 fossil record in the form of huge tunnels (up to $2 \mathrm{~m}$ wide), with horizontally flattened elliptical

79 cross-sections from Argentina and Brazil (e.g., Quintana, 1992; Vizcaíno et al., 2001;

80 Buchmann, Pereira Lopes \& Caron, 2009; Genise \& Farina 2012; Frank et al., 2012; 2015). The

81 smaller burrows are attributed to Dasypodidae and Pampatheriidae and the larger to ground

82 sloths. It has been suggested that the adoption or generalization of burrowing behavior by large

83 Pleistocene herbivorous mammals may reflect the arrival of large carnivorans after the Great

84 American Biotic Interchange, just before the Pliocene-Pleistocene boundary (Soibelzon et al., 85 2009).

86 A trend towards larger diameter burrows is evident from the early Miocene to the late

87 Pleistocene (see Fig. 1). Pre-Miocene burrows attain a maximum average horizontal diameter 
88 (Dh) of $420 \mathrm{~mm}$ (the examples from the Navajo Sandstone described by Loope, 2006), however,

89 most are in the range of 100-200 mm. From the Miocene on, burrows with an average horizontal

90 diameter in excess of $500 \mathrm{~mm}$ are recorded (Fig. 1), including those studied herein. The Neogene

91 record also includes more common and smaller burrows (Dh < $200 \mathrm{~mm}$ ) that are mostly

92 attributed to rodents and small Dasypodidae (Fig. 1).

93 In this context, the tetrapod burrows from the late Miocene Cerro Azul Formation are the

94 largest pre-Pleistocene tetrapod burrows and can help to understand the reasons for acquisition of

95 burrowing habits in large Cenozoic mammals from South America. These structures have been

96 partially and briefly described (Genise et al., 2013), but a detailed description has yet to be done

97 and is an objective of this study. The purposes of this work are: 1) to infer the likely producers of

98 these late Miocene large burrows and 2) to interpret the taphonomic processes involved in the

99 preservation of the burrow casts and its paleoecological and paleoenvironmental meaning.

\section{Material \& methods}

101 The studied localities with late Miocene burrows are distributed in a latitudinal belt of 102 approximately 25 km (Fig. 2): Salinas Grandes de Hidalgo (SG, 37 12' 55'S, 63 35' 25’W;

103100 masl); Laguna Chillhué (LC, 37²19'15.13"S; 64¹4'31.52"W; 145 masl); and Laguna La

104 Paraguaya near Carhué city (LLP, $37^{\circ} 5^{\prime} 53.57^{\prime \prime S}$; 6247'34.98"W; 101 masl). The first two

105 localities belong to La Pampa province, whereas the remaining is located in the adjacent Buenos

106 Aires province. The burrow fills appear in outcrop as transverse to oblique, longitudinal,

107 tangential and plan view exposures.

108 Another locality of the Cerro Azul Formation, a roadcut in national road $154\left(\mathrm{R} 154,37^{\circ}\right.$

109 49' 28.5'S, 64 4' 8.9'W), has been previously described as having vertebrate burrows (De

110 Elorriaga \& Visconti, 2001). However, this locality is not considered herein because the burrows 
111 probably postdate significantly the deposition of the unit. The reasons for this inference are: 1)

112 burrow diameters are considerably larger than those described herein (Dv up to $2.25 \mathrm{~m}$ ) and

113 more consistent with burrows attributed to a large Pleistocene megafauna (e.g., Vizcaíno et al.,

114 2001; Frank et al., 2012); and 2) the burrow cut the carbonate nodules of the capping calcrete.

115 Although absolute dating of the calcrete is not available, it has been suggested that the

116 calcretization process significantly postdates the deposition of the Cerro Azul Formation (Vogt,

117 Carballo \& Calmels, 1999; Melchor \& Casadío 2000; Visconti et al., 2010). The main argument

118 for this inference is that the calcrete is developed in sedimentary sequences ranging in age from

119 late Miocene to Pleistocene.

120 Standard measurements in burrows were horizontal diameter (Dh), vertical diameter

121 (Dv), preserved length, mean azimuth of burrow fill and inclination of fill laminae. The mean

122 azimuth was measured using a compass and considering the burrow fill boundary and dominant

123 plunge of laminated fill. When changes of dip direction or inclination were observed in a single

124 burrow fill they were recorded separately. Burrow diameter (especially Dh) was measured

125 orthogonal to the main axis of the structure. The horizontal diameter was obtained from almost

126 all types of exposures (except for longitudinal ones), whereas the vertical diameter was mostly

127 an apparent value, except for the rare transverse sections, where it can be considered the true

128 vertical diameter. At each location, GPS coordinates were recorded; the burrow fills were

129 photographed and sketched.

130 The burrow fills exposed in transverse section $(n=24)$ were used for a 2-D geometric

131 morphometric analysis. From field photographs, the outline of the burrow boundary was

132 sketched in Corel Draw ${ }^{\mathrm{TM}}$. These images were used to build a file with the TPSutil software.

133 Burrow cross section outlines were oriented with respect to the top and bottom of the hosting bed 
134 and treated as symmetrical outlines. For each image a total of 16 type II landmarks (Slice et al.

135 2008) were digitised using the TPSdig2 software- Landmark 1 and 9 were positioned in the

136 intersection of the burrow outline and the maximum vertical axis, whereas landmarks 5 and 13

137 resulted from the intersection of the maximum horizontal axis with the burrow outline. The

138 remaining landmars were arranged with an equidistant pattern on the burrow outline (Fig. 3 and

139 Supplemental Article S2). Landmarks were aligned using the Procrustes superposition method

140 (McLeod, 2009) and the principal component analyses (PCA) using MorphoJ software. Results

141 are presented by eigenvalue diagrams and PC scores, along with transformation grids.

142 From scaled sketches of transverse sections of burrow fills, the cross-sectional area of the

143 burrow was estimated using ImageJ software. This cross-sectional area was used to estimate the

144 body mass of the producer using the allometric relations of Wu et al. (2015).

At each locality, a detailed sedimentary log was measured and samples of host rock and

146 burrow fill were collected for petrographic analysis. At selected locations also a detailed

147 sedimentologic log of the burrow fill was measured. Mammal bones found in situ within burrow

148 fills were recorded and collected for preparation and taxonomic identification. Fossil bones

149 found outside burrows were not recorded or collected. Fossil remains from La Pampa province

150 collected during this study are housed at the Paleontological Collection of the Facultad de

151 Ciencias Exactas y Naturales, Universidad Nacional de La Pampa, Santa Rosa city, La Pampa,

152 Argentina, under the acronym GHUNLPam. Fossil material collected in burrows from Laguna

153 La Paraguaya locality (Buenos Aires province) are housed at the Museo Histórico Regional de

154 Guaminí "Coronel Marcelino E. Freyre" under the acronym MHG-P. Field work was approved

155 by the Dirección Provincial de Museos y Preservación Patrimonial, under the Project

156 "Vertebrados del Mioceno tardío-Plioceno en el área de las lagunas encadenadas del oeste de la 
157 provincia de Buenos Aires. Aportes a la bioestratigrafía del Cenozoico tardío de la Región

158 Pampeana", permit nr. 2015-3-P-156-2.

\section{Geological setting}

160 The Cerro Azul Formation outcrops are located in the north-western, central, and eastern part of

161 La Pampa province and adjacent western Buenos Aires province, Argentina (Linares, Llambías

162 \& Latorre, 1980; Folguera \& Zárate 2009; Visconti et al., 2010). The unit is characterized by a

163 monotonous succession of loess containing moderately developed paleosols (Fig. 4) that has

164 been assigned to the late Miocene (Huayquerian Land Mammal age) essentially on the basis of

165 its mammal remains (Montalvo \& Casadío, 1988; Verzi, Montalvo \& Vucetich, 1999; Verzi,

166 Montalvo \& Visconti, 2003). In particular, the formation is considered as representing the

167 interval between 10 and 5.7 Ma (Cione et al., 2000; Verzi, Montalvo \& Deschamps, 2008). The

168 maximum exposed thickness in outcrop is $54 \mathrm{~m}$, although the unit reaches about $180 \mathrm{~m}$ in the

169 subsurface (Visconti et al., 2010). The formation is essentially composed of structureless, light

170 brown (5YR 6/4), pale reddish brown (10R 5/4) or grayish orange pink (5YR 7/2), sandy

171 siltstones and fine-grained sandstones, showing moderate selection and common carbonate

172 cementation.

\section{Results}

\section{Sedimentology of the burrow - bearing sections}

175 Macroscopic features of the studied sections are very similar to those of the classical localities of

176 the Cerro Azul Formation outcrops (e.g., Visconti et al., 2010; Genise et al., 2013; Cardonatto et

177 al., 2016), especially those of the Salinas Grandes de Hidalgo and Laguna La Paraguaya.

178 Paleosol profiles are typically composed of two horizons (Fig. 4). The upper horizon is a clayey 
179 siltstone that is distinguished by the presence of subangular blocky, granular or prismatic peds

180 and a darker color (5 YR 6/4) than the underlying horizon. Carbonates are rare except for the

181 local occurrence of calcareous rhizoliths. This upper horizon can be compared with a Bt horizon

182 and its thickness averages $0.60 \mathrm{~m}($ range $=0.35-1.00 \mathrm{~m}, \mathrm{n}=5)$, which is very close to the

183 average for the formation (Cardonatto et al., 2016).

184 The lower horizon is characterized by lighter colored (5 YR 7/2), siltstone to fine- grained

185 sandstone with pervasive carbonate cementation, both in the form of nodules and rhizoliths.

186 Rhizoliths are small to medium sized and commonly 1-30 $\mathrm{mm}$ in diameter. The lower horizon

187 can be up to more than $5 \mathrm{~m}$ thick and contain relicts of primary sedimentary structures, like

188 tangential cross-bedding or horizontal bedding, as seen in the Salinas Grandes de Hidalgo section

189 (Fig. 4). Mudstone intraclasts are common throughout. The remains of primary sedimentary

190 structures and carbonate cementation suggest comparison with a Bk or Bk/C horizon. The trace

191 fossils described in this paper occur in both horizons.

192 The section at Laguna Chillhué also contains similar paleosols (Fig. 4) and differs from

193 the other localities by the presence of a 2 m thick, dark-red, laminated mudstone interval in the

194 lower part of the section (Montalvo et al., 1995). The presence of a mudstone interval in the

195 lower section of the Cerro Azul Formation has been questioned by Lorenzo, Mehl \& Zárate

196 (2013), who supposed a younger age for this mudstone interval on the basis of geomorphological

197 inferences. However, at this location the laminated mudstone interval is overlain, through a

198 normal sedimentary contact, by lithologies typical of the Cerro Azul Formation containing

199 mammal remaims of Huayquerian (late Miocene) age, with no evidence of reworking. Vertebrate

200 burrow fills were not observed in the laminated mudstone interval. 


\section{Description of large burrow fills}

202 A total of 115 fossil burrows were measured from three localities: 53 from Salinas Grandes de 203 Hidalgo, 59 from Laguna La Paraguaya, and 3 from Laguna Chillhué (see Supplemental Table

204 S1). The studied burrow fills are distinguished on the basis of the presence of a thinly laminated 205 siltstone to mudstone interval that contrasts with the structureless host rock. When the upper part 206 of the fill is massive and similar in grain size to the host rock, the upper burrow boundary is 207 indistinct. Burrow fills exhibit an induration, composition and cementation similar to the hosting 208 rocks, suggesting that they are too of late Miocene age. At Laguna La Paraguaya locality, the 209 preferential carbonate cementation of the burrow fills resulted in 3-D exposures (Fig. 5A). At 210 this locality the density of fossil burrows is locally high and may be difficult to find unburrowed 211 intervals. Cross-cutting relationships between two or more burrows are common (Figs. 5B, 5C).

212 Size and plan view pattern

213 Observed horizontal diameter $(\mathrm{Dh})$ ranges from 0.15 to $1.50 \mathrm{~m}(\mathrm{n}=112)$ and the

214 frequency distribution suggests a roughly normal distribution where three subpopulations can be

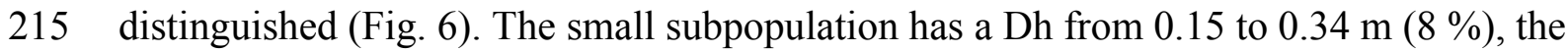

216 intermediate subpopulation has a $\mathrm{Dh}$ from 0.39 to $0.98 \mathrm{~m}(84 \%)$, and the large subpopulation

217 exhibits a Dh from 1.05 to $1.50 \mathrm{~m}(8 \%)$.

218 In plan view exposure, which is found only at SG and LLP localities $(\mathrm{n}=78)$, a number of 219 morphologies can be distinguished (Fig. 7). 1) The more common are straight to slightly curved 220 burrows ( $89 \%$ of cases), which exhibits a $\mathrm{Dh}=0.15-1.15 \mathrm{~m}$, showing a uniform inclination of 221 internal laminae (ranging from $\approx 0^{\circ}$ to $27^{\circ}$ ), the maximum height difference between the 222 proximal and distal portion of a burrow is $0.6 \mathrm{~m}$, and the maximum preserved length is $5.18 \mathrm{~m}$ 223 (Figs. 7A, 7B). Some burrow fills in this category display a decrease in inclination of internal 
224 laminae toward more distal positions (i.e., from $27^{\circ}$ to $8^{\circ}$ ). 2) A sinuous burrow that displays two

225 opposite curves in plan view was recorded in $5 \%$ of the cases (Figs. 7C, 7D). The horizontal

226 diameter of sinuous burrow ranges from 0.42 to $0.80 \mathrm{~m}$, dip of internal laminae is subhorizontal

227 to slightly inclined (up to $8^{\circ}$ ), and the maximum observed length is $8 \mathrm{~m} .3$ ) The third plan view

228 pattern is a C-shaped curve observed in $6 \%$ of the burrows, with an horizontal diameter ranging

229 from 0.44 to $0.72 \mathrm{~m}$ (Figs. 7E, 7F), which commonly appears as a ramp with a height difference

230 of up to $0.55 \mathrm{~m}$, the inclination of internal laminae can be uniform (from $3^{\circ}$ to $12^{\circ}$ ) or show a

231 shallowing toward the distal position (from $14^{\circ}$ to subhorizontal).

232 In a few cases, the distal portion of burrow showed a lateral expansion of up to $23 \%$ of

233 the Dh, commonly having a subhorizontal lamination (Figs. 7G, 7H). Other burrow fills exhibit a

234 rounded end with no enlargement that can be accompanied by an upward bending of mudstone

235 laminae against the walls of the burrow.

236

237

238

239

240

241

242

243

244

\section{Cross-sectional shape and body mass}

The analysis of the well defined cross-sectional shape of burrows ( $\mathrm{n}=24$ from all

localities) suggest a distinction between elliptical (with the major axis subhorizontal) and subcircular cross-sections. Elliptical cross-sections are more common $(\mathrm{n}=18)$ and the corresponding Dh ranges from 0.39 to $1.50 \mathrm{~m}$ (belonging to the intermediate and large subpopulations, Fig. 6), with an average Dv/Dh ratio of 0.55 . The burrows s with elliptical crosssection include a few cases $(\mathrm{n}=4)$ with a flat bottom and convex top. The subcircular crosssectional shape $(\mathrm{n}=6)$ is represented in the intermediate subpopulation with a $\mathrm{Dh}$ ranging from 0.39 to $0.56 \mathrm{~m}$, and an average $\mathrm{Dv} / \mathrm{Dh}$ ratio of 0.88 . 

principal components (Fig. 8B), and deformation grids range from elliptical (score $=-0.12$ ) to 247 subcircular $($ score $=0.17)($ Fig. 8A).

248 Body mass estimates of the producers of the burrow on the basis of the cross-sectional 249 area (using the method by Wu et al., 2015) suggest that there are two ranges (Table S1). Most of 250 the estimates $(n=18)$ belongs to the intermediate subpopulation with a range from 37 to $439 \mathrm{~kg}$, 251 whereas the remaining estimates comes from the large subpopulation $(n=7)$ with a range 708 to $2521623 \mathrm{~kg}$. Burrows with subcircular cross-section from the intermediate subpopulation, are linked 253 with a producer having body mass from 92.84 to $186.0 \mathrm{~kg}$.

\section{Orientation and inclination}

Readings of plunge azimuths of burrow fills from all localities are variable but most values are located in the northeast to southeast quadrants (i.e., between N20 and N140 ${ }^{\circ}$ (Figs. 9A, 9C). The average dip angle of all measured burrows with respect to the paleohorizontal is $7.25^{\circ}$ and ranges from nearly 0 to $27^{\circ}$ (Fig. 9B). Most orientation data come from the intermediate subpopulation $(\mathrm{Dh}=0.39-0.98 \mathrm{~m})$ and especially from LLP locality.

260

\section{Composition of burrow fills}

The vertebrate burrows are easily spotted in the field because of the distinctive laminated structure of the infilling sediments that contrasts with the structureless host rock. The filling is composed of an alternation of laminated claystone and siltstone with massive fine-grained sandstone and siltstone containing floating claystone intraclasts. Laminated intervals are a few millimeters to about $50 \mathrm{~mm}$ thick, whereas massive intervals tend to be thicker. Most of the burrow fills display a laminated interval in the lowermost part of the fill, with the upper part 
267 massive, especially in the Salinas Grandes de Hidalgo locality (Figs. 10A, 10B, 10C). A few

268 burrows display a poorly defined lamination to massive structure throughout (Fig. 10D).

269 Claystone and siltstone laminae at the bottom of the structure typically deflect upwards against

270 the burrow wall, which is a good criterion to distinguish burrow fills that are mostly exhumed by

271 erosion. Laminae tend to be horizontal but successive laminated packages resting at low angles

272 were also identified. Individual laminae are normally graded (typically siltstone grading to

273 claystone), and locally disrupted giving a brecciated aspect. Both synsedimentary faulting and

274 deformation were identified (Fig. 10F). A pseudomeniscate structure was identified in two cases

275 (one from Salinas Grandes de Hidalgo and the other from Laguna La Paraguaya). This structure

276 is composed of massive siltstone or fine-grained sandstone arranged in adjacent crescent-shaped

277 bodies with the convex margin pointing downslope that span the full width of the fill (Fig. 10E).

278 Horizontal width of individual pseudomeniscate bodies taken parallel to the burrow axis is 120

$279 \mathrm{~mm}$.

280 Associated ichnofossils

281 Only the ichnofossils found within or very close to the burrow fills are considered. We

282 found within the fills abundant rhizoliths and rare smaller vertebrate burrows, vertebrate

283 footprints and ?Rosellichnus isp. In the paleosol adjacent to the fills we found Taenidium

284 barretti, Attaichnus kuenzelli and Coprinisphaera isp.

285 Calcareous rhizoliths, including rhizocretions and root casts, are abundant and were

286 recorded in all studied localities. Rhizoliths are arranged in vertical, oblique and subhorizontal

287 position (Fig. 10C). Rhizoliths are submillimeter to $45 \mathrm{~mm}$ thick and the maximum preserved

288 length is $500 \mathrm{~mm}$. Rhizoliths occurring inside burrow fills are similar in shape and cementation

289 to those of the hosting rock. 
A single small burrow (Fig. 11A) that cuts the laminated interval of a larger vertebrate

291 burrow fill was identified at Salinas Grandes de Hidalgo (\# 638). The $43 \mathrm{~mm}$ in diameter

292 structure displays a subcircular outline and a poorly laminated siltstone fill.

293 A partially eroded burrow fill from Laguna La Paraguaya (\# 708) exposed an internal

294 bedding plane of the filling showing closely spaced elliptical depressions with a noticeable

295 marginal rim (Fig. 11C). These are tentatively interpreted as footprints of a quadrupedal animal

296 composing a $316 \mathrm{~mm}$ wide trackway. If this is a trackway a pace angulation of $112^{\circ}$ and a stride

297 length of $600 \mathrm{~mm}$ can be inferred. Measurements on individual footprints indicate that average

298 footprint length is $144 \mathrm{~mm}$, average footprint width is $93 \mathrm{~mm}$, and the marginal rim is of uniform

299 thickness and about $50 \mathrm{~mm}$ wide.

$300 \quad$ A group of five subcircular rings in the upper part of a burrow fill (\# 659A from SG) is

301 tentatively identified as a cluster of bee cells and compared with the ichnogenus Rosellichnus

302 (Fig. 11D). The presence of the ichnogenus at this locality, although at other section, was already

303 documented by Cardonatto et al. (2016).

304 Adjacent to the burrow fills at Salinas Grandes de Hidalgo, several specimens of

305 Attaichnus kuenzelii were identified, in some cases very close, but no cross-cutting relationship

306 were seen. A few specimens of Taenidium barretti also occur at this locality, in the form of

307 subcylindrical burrows, $12 \mathrm{~mm}$ wide and $80 \mathrm{~mm}$ long with an average meniscus thickness of 2.2

$308 \mathrm{~mm}$. At Laguna La Paraguaya we also found two specimens of cemented and compact spherical

309 chambers (diameter 18.7-23.0 mm) with a large emergence hole (10-11 mm) assigned to

310 Coprinisphaera isp. (Fig. 11B). 


\section{Bone remains found within burrow fills}

312 Mammal bones within the burrow fills are scarce (only 1\% of burrows contained fossil remains)

313 and usually appear disarticulated and poorly preserved, in some cases with signs of abrasion

314 (Fig. 12A). The fossil remains from the SG locality are Proscelidodon sp. and Glyptodontidae

315 indet., whereas the rest of the fossil material was found at LLP locality, including: Paedotherium

316 minor (two specimens), Doellotatus sp., Eosclerocalyptus sp., Mesotheriinae indet.,

317 Gyptodontidae indet. (three specimens), and undeterminate mammals (two specimens). For

318 details about the taxonomy and illustrations of mammal remains, see Supplemental Article S3

319 and Supplemental Figure S1. The only articulated remains are glyptodont osteoderms found at

320 Laguna La Paraguaya (\# 702) that are assigned to Eosclerocalyptus sp. (Fig. 12B), and remains

321 of a carapace with several articulated osteoderms from the same locality (\# 670) assigned to

322 Glyptodontidae indet. Proscelidodon sp. remains (including a hemimandible with teeth and

323 postcranial elements) appeared disarticulated but associated within a single burrow fill. The

324 fossil remains display different degree of weathering and corrosion, as well as biostratinomic

325 fractures.

326 Discussion

\section{Producers}

328 The studied fossil burrows are unbranched and display a significant variation in the horizontal

329 diameter, which ranges from $0.15 \mathrm{~m}$ to $1.5 \mathrm{~m}$ (Fig. 6). The simple, ramp type morphology of the

330 studied burrows suggests that the animals foraged aboveground (e.g., Reichman \& Smith, 1990).

331 In order to infer the likely producers of the fossil burrows there are several constraints that need

332 to be considered: 1) the faunal remains found inside the burrow fills; 2) the fossorial mammals

333 that were recorded in the Cerro Azul Formation, especially those from the studied localities; 3 ) 
334 the size of burrows, as expressed by the $\mathrm{Dh}$; and 4) the overall architecture and cross-section of

335 burrows (including the Dv/Dh ratio) and the extrapolated body mass of its digger. The surface

336 ornamentation of burrows is commonly a very useful clue to the producer (e.g., Seilacher, 2007),

337 however, it is not preserved in the studied cases.

338 Faunal remains found in burrow fillings

339 In general, bone remains found inside a burrow can be considered as belonging to its producer or

340 occupant only if they are articulated, disarticulated but still closely associated, nearly complete,

341 are commonly found in a terminal portion and fit the size (cross-sectional diameter) of the

342 burrow (e.g., Smith, 1987; Groenewald, Welman \& MacEachern, 2001; Damiani et al., 2003).

343 The remains found inside the studied burrows do not fulfill any of these criteria. In most cases,

344 these bone remains have been passively introduced and it is uncertain if they belong to the

345 producers. The remains are essentially fragmentary, disarticulated, with evidence for abrasion

346 and weathering (Fig. 12A, S1); suggesting that they spent some time at the surface and then were

347 introduced into the burrows by currents along with other sedimentary particles. The fragmentary

348 and disarticulated state of Doellotatus sp. and one of the specimens of Paedotherium minor and

349 the considerably small size of the animals (body mass about 1-2 kg, Table 1) in comparison with

350 the containing burrows; further suggest that these remains were introduced by currents. In the

351 case of Proscelidodon sp., the bones are disarticulated but associated, which suggest that they

352 can belong to a single specimen, and the partial horizontal diameter of the burrow match the size

353 of this ground sloth. The only articulated remains are fragments of the dorsal carapace of

354 Glyptodontidae that occur in burrows large enough to hug these animals $(\mathrm{Dh}=0.78$ to $1.50 \mathrm{~m})$

355 (Table 1). In consequence, the unique remains that can belong to the producer of the burrows are 356 Proscelidodon sp. and those of Glyptodontidae. 
357 Fossorial mammals of the Cerro Azul Formation and size of burrows

358 The mammals with fossorial habits recorded in the Cerro Azul Formation include xenarthrans,

359 notoungulates and rodents (e.g., Goin, Montalvo \& Visconti, 2000; Cerdeño \& Montalvo 2001;

360 Urrutia, Montalvo \& Scillato-Yané, 2008). Among the Xenarthra, the Glyptodontidae,

361 Dasypodidae and Mylodontidae display fossorial adaptations. The same is true for Mesotheridae

362 and Hegetotheriidae (Notoungulata); and Caviidae, Octodontidae, and Chinchillidae (Rodentia).

363 Below we discuss the potential producers for each size class of the burrows (Table 1) as

364 expressed by the horizontal diameter and cross-sectional area of the burrows.

365 For the small subpopulation ( $\mathrm{Dh}=0.15-0.34 \mathrm{~m}, 8 \%$ of cases), with a body mass ranging from 1

366 to $13 \mathrm{~kg}$, the likely candidates are the notoungulate Paedotherium minor, the dasypodids

367 Doellotatus, Chorobates, Proeuphractus, and Chasicotatus; and the rodent Lagostomus.

368 Paedotherium (Hegetotheriidae) is a medium-sized rodent-like ungulate native to South

369 America. This taxon is very common in the Cerro Azul Formation, both in La Pampa and

370 Buenos Aires provinces (e.g., Montalvo, Tomassini \& Sostillo, 2016). Articulated remains of this

371 genus have been found within Pliocene burrow casts (about $0.16-0.22 \mathrm{~m}$ wide) from the Atlantic

372 coast of Buenos Aires province (e.g., Genise, 1989; Scognamillo, 1993; Elissamburu, Dondas \&

373 De Santis, 2011) and a morphofunctional analysis of its postcranial skeleton suggest a digging

374 capacity (Elissamburu, 2004).

375 The Dasypodidae show a neotropical geographic distribution and were important components of

376 the late Miocene-Pliocene South American fauna (Scillato-Yané, 1982; Ortiz Jaureguizar, 1998).

377 Dasypodids exhibit fossorial habits and were abundant during the late Miocene in the Pampean

378 region of Argentina, suggesting preference for open environments and well drained soils

379 (Scillato-Yané et al., 2013). Most dasypodids recorded in the Cerro Azul Formation were small-

380 to medium-sized, with body mass in the range 1-10 kg for Doellotatus, Chasicotatus, 
381 Proeuphractus and Chorobates (Table 1). In particular, the holotype of Chasicotatus ameghinoi

382 is a nearly complete carapace about $150 \mathrm{~mm}$ wide (Scillato-Yané, Kromptic \& Esteban, 2010),

383 which match the lower size range of the small subpopulation. Modern dasypodid burrows are

384 usually simple ramps lacking significant enlargements (e.g., González, Soutullo \& Altuna, 2001;

385 Abba, Udrizar \& Vizcaíno, 2005), which is similar to the architecture of the fossil burrows.

386 In the same localities of Paedotherium-bearing burrows from the Atlantic coast of the Buenos

387 Aires province, there are also burrows containing articulated remains of Lagostomus that

388 partially overlap in diameter with those containing Paedotherium remains (Genise, 1989;

389 Elissamburu, Dondas \& De Santis, 2011). The extant Lagostomus maximus (plains vizcacha) is

390 well known for its digging adaptations and for living in communal burrow systems (e.g.,

391 Jackson, Branchi \& Villarreal, 1996). Plains vizcacha burrow systems show an average entrance

392 horizontal diameter of $0.26 \mathrm{~m}$ and a range of 0.17-0.37 $\mathrm{m}$ (Llanos \& Crespo, 1952), which

393 matches the range of the small subpopulation. However, extant L. maximus burrow systems have

394 several entrance ramps that typically converge into a central chamber or a much more complex

395 architecture (e.g., Llanos \& Crespo, 1952; Rafuse et al., 2017), which contrast with the simple

396 ramp type morphology of the fossil burrows. The $43 \mathrm{~mm}$ in diameter subcircular burrow

397 identified in the fill of a larger burrow at Salinas Grandes de Hidalgo (\# 638) is probably related

398 to a caviomorph rodent (Caviidae, Octodontidae or Chinchillidae).

399 For the dominant intermediate subpopulation ( $\mathrm{Dh}=0.39-0.94 \mathrm{~m}, 83 \%$ of measured burrows),

400 with an estimated body mass ranging from 37 to $438 \mathrm{~kg}$, the likely candidates are the

401 Mesotheriinae (Mesotheriidae, Notoungulata); Eosclerocalyptus, Coscinocercus, and

402 Aspidocalyptus (Xenarthra, Glyptodontidae); Macrochorobates and Macroeuphractus

403 (Xenarthra, Dasypodidae); and Proscelidodon (Xenarthra, Mylodontidae). The fossil remains 
404 found in this size range that are likely candidates are those of Glyptodontidae and Proscelidodon 405 sp. (Table 1). There are two Mesotheriinae species recognized for the late Miocene of central 406 Argentina: Pseudotypotherium subinsigne and Typotheriopsis silveyrai (Cerdeño \& Montalvo, 407 2001). These species exhibited a small to medium size (20.88 to $60.13 \mathrm{~kg}$ after Croft, Flynn \& 408 Wyss, 2004) (Table 1). The Mesotheriidae shows modifications in the appendicular skeleton that 409 suggest a scratch-digging habit and fossorial adaptations and are envisaged as having used its 410 hypsodont teeth to cut roots and break the substrate, to aid digging with claws (Shockey et al., 411 2007).

412 Kraglievich (1934) and Quintana (1992) suggested that glyptodonts were not functionally suited 413 for digging. However, a geometric morphometric study of the limb bones of five glyptodont 414 species of Miocene and Pleistocene age and comparison with extant armadillos led Vizcaíno et 415 al. (2011) to conclude that were generalized diggers, as modern Dasypodini and Euphractini.

416 Generalized diggers are species that dig short burrows for protection or in search of food and that

417 feed on the surface or just below it by making 'food probes' (Abba, Udrizar \& Vizcaíno, 2005).

418 In order to asses if glyptodonts were likely producers of the fossil burrows we compared the 419 width of the dorsal carapace and the dorsal carapace height / width ratio with comparable values 420 of the fossil burrows. Dorsal carapace width of Miocene-Pliocene glyptodonts range between 4210.40 and $0.77 \mathrm{~m}$ (Perea, 2005; Vizcaíno et al., 2011; Zurita et al., 2011), well in the range of 422 horizontal diameter of the fossil burrows. Information on the ratio between carapace height and 423 width for Miocene-Pliocene glyptodonts is incomplete, and similar data for Pleistocene South 424 American glyptodonts (Duarte, 1997; Zurita et al., 2010) average 0.87 (range=0.78-0.91; $\mathrm{n}=4$ ).

425 In our case study, glyptodonts are considered good candidates for constructing the subcircular 426 burrows of the intermediate subpopulation, which are $0.39-0.56 \mathrm{~m}$ wide and display an average 
427 Dv/Dh ratio of 0.88. Regarding the large dasypodids Macrochorobates and Macroeuphractus,

428 the available body mass estimates suggest a range of 10 to $100 \mathrm{~kg}$ (Vizcaíno \& Fariña, 1999) and

429 little is known about their paleoecology.

430 Among the mylodontids, the Scelidotherinae, endemic to South America (McDonald, 1987;

431 Taglioretti et al., 2014); are only represented for the Huayquerian - Chapadmalian SALMAs

432 (late Miocene to early Pliocene) by Proscelidodon, a ground sloth related to open environments

433 with grasslands, under temperate and warm climate (Miño Boilini et al., 2011; Pujos et al., 2012;

434 McDonald \& Perea 2002). A digging habit was inferred for Proscelidodon after a

435 morphofunctional study of a Montehermosian (latest Miocene-early Pliocene) forelimb

436 (Aramayo, 1988). Body mass estimates are only available for Pleistocene scelidotherines (Table

437 1) and range from 584 to $1057 \mathrm{~kg}$ (De Esteban-Trivigno, Mendoza \& De Renzi, 2008; Bargo et

438 al., 2000; Fariña, Vizcaíno \& Bargo, 1998). These would be maximum estimates for late

439 Miocene scelidotherines because the primitive Mylodontidae were smaller and there seems to be

440 a trend toward progressively larger sizes in the Pleistocene (e.g., McDonald \& Perea 2002).

441 Large Pliocene-Pleistocene fossil burrows near Mar del Plata city (Buenos Aires province) have

442 been attributed to mylodonts on the basis of the finding of bone remains inside the fill

443 (Frenguelli 1955) and using the surface ornamentation of the burrows (Zárate et al., 1998;

444 Dondas, Isla \& Carballido, 2009).

445 For the large subpopulation, with a Dh ranging from 1.05 and $1.50 \mathrm{~m}$ ( $9 \%$ of cases) and an

446 extrapolated body mass of 700-1600 kg, the more likely producer is Proscelidodon sp. and,

447 secondarily, the Glyptodontidae.

448 To summarize, the studied fossil burrows can be attributed to several producers, according to

449 their horizontal diameter. The more likely producers of the studied fossil burrows are: 1) for the 
450 small subpopulation, the smaller dasypodids (Doellotatus, Chasicotatus, Proeuphractus and

451 Chorobates) on the basis of body mass, the fossorial habit and architecture of modern dasypodid

452 burrows and, secondarily, Paedotherium minor. 2) For the intermediate and large

453 subpopulations, the Glyptodontidae and Mylodontidae (Proscelidodon sp.) are good candidates

454 as these were the largest representatives of the late Miocene burrowing fauna of the Cerro Azul

455 Formation. The Glyptodontidae were generalized diggers, like modern dasypodids, and exhibited 456 a carapace fitting especially the subcircular burrows. Proscelidodon sp. is also a likely candidate

457 of the elliptical and larger burrows. For the intermediate subpopulation, probably the large

458 dasipodids (Macrochorobates and Macroeuphractus) and Mesotheriinae should be considered.

459 Taphonomy of burrows

460 The horizontally laminated and massive fill of the burrows suggest that the material entered the

461 excavation passively, that is after the burrow had been fully excavated, and without any

462 assistance by the digger. The infill also indicates that the burrows were abandoned and received

463 sediments in successive small pulses and large catastrophic events. Although we cannot discard

464 some secondary input of dust by wind, most of the filling of the burrows is related to water

465 transport as indicated by the well laminated and normal graded siltstone to mudstone laminae

466 (Figs. 10A-C, 10F). Laminated intervals are linked to successive pulses of sediment-laden water

467 that eventually ponded in the terminal tracts of the burrows. This is in agreement with the

468 interpretation by Imbellone, Teruggi \& Mormeneo (1990) of similar Quaternary burrows and

469 experimental results by Woodruff \& Varricchio (2011). Experiments by Woodruff \& Varricchio

470 (2011) indicate that well-laminated fills were obtained by adding small amounts of sediment-

471 water mixtures entering at a low angle $\left(5^{\circ}\right)$ into the burrow. In contrast, en masse pouring of the

472 sediment-water mixture at high angle $\left(30^{\circ}\right)$ produced a massive and poorly sorted sediment fill, 
473 whereas en masse pouring at a low angle $\left(5^{\circ}\right)$ produced thicker graded beds (Woodruff \&

474 Varricchio 2011). En masse filling experiments also produced "arcuate structures" (Woodruff \&

475 Varricchio 2011) that are very similar to the pseudomeniscate structures described herein. Both

476 features are comparable to "arcuate surface ridges" produced in experimental debris flows that

477 reflect the pulsatory nature of experimental and natural debris flows (Major, 1997). The

478 experiments by Woodruff \& Varricchio (2011) lend further support to the interpretation of the

479 massive intervals as result of catastrophic input of large volume of unsorted sediment. As the

480 burrows are related to an essentially flat landscape and no fluvial channel deposits were observed

481 in any of the studied localities, the sediment pulses should be related with rainfall. We speculate

482 that one or more laminae may result from moderate to heavy precipitation events. In contrast,

483 massive intervals can be related to single heavy downpours producing sheet flooding, which can

484 generate hyperconcentrated flows (e.g., Smith \& Lowe, 1991) capable of transporting enough

485 material to fill, at least, the terminal portion of a burrow in a single event. High-energy sheet

486 floods can also saturate burrow walls and produce roof collapse.

487 Our studies also support the generalization that well laminated burrow fills will not contain

488 remains of the producer and that massive fills of the whole burrow or most of the lower part have

489 a greater chance of containing remains of the tetrapod that dug the burrow, as proposed by

490 Scognamillo (1993) and Groenewald, Welman \& MacEachern (2001). For the laminated burrow

491 fills, the most likely scenario is that the burrow was vacated or, if the animal died inside, it may

492 result scavenged and/or weathered, which produces incomplete and disarticulated remains. In the

493 case of a massive fill, both live entombing (Scognamillo, 1993; Groenewald, Welman \&

494 MacEachern, 2001) and fast burial after death (Woodruff \& Varricchio, 2011) are required to 
495 produce a nearly articulated and complete skeleton. Massive fills in the upper half of the burrow

496 will not preserve remains of its producer.

497 The episodic nature of the filling processes is evidenced by the laminated fill and further

498 supported by the presence of footprints in the surface of some laminae and the cluster of bee

499 cells (?Rosellichnus isp.) found inside the fill. These trace fossils suggest that partially filled

500 burrows with a surface communication were explored or reoccupied by other tetrapods and used

501 by bees to nest. Alternatively, the bee cells may be constructed after the complete filling of the

502 burrow in the soil profile. Among the presumed producers of burrows of intermediate size, the

503 outline and size of the footprints match those of Pleistocene glyptodonts but are quite different

504 from those of ground sloths (compare Aramayo et al., 2015). Disruption of laminae composing

505 the fill of the burrows is explained by drying and cracking of mud after a flood event, whereas

506 synsedimentary faulting can be related to trampling by tetrapods.

507 Attaichnus kuenzelli occur profusely in the SG locality, in some cases very close, but never were

508 cut by a large mammal burrow. These relationships suggest that the producers of the burrows

509 were apparently not foraging on A. kuenzelli, considered a nest chamber of leaf-cutting ants

510 (Genise et al., 2013).

511 Paleoecological and paleoenvironmental meaning

512 Detailed inferences about the paleoecological and paleoenvironmental meaning of the studied

513 large mammal burrows can be gained through sedimentological study of the hosting rocks,

514 analysis of orientation of fossil burrows and considering the associated trace fossils. This

515 information, along with the potential producers will help to understand the reason for acquisition

516 of burrowing habits in large late Miocene mammals. 


\section{Sedimentology}

518 Thick, monotonous, massive continental successions of siltstone showing moderate to good

519 sorting with associated paleosols, as those described for the Cerro Azul Formation, are typical of 520 loess deposits, whose dominantly eolian origin is well established (e.g., Johnson, 1989; Pye,

521 1995). The presence of pedogenic calcite is indicative of well-drained soil profiles in sub-humid, 522 semi-arid, and arid climates with low rainfall (less than $800 \mathrm{~mm} / \mathrm{yr}$ ) and high evapotranspiration

523 (see review in Sheldon \& Tabor, 2009). Previous estimation of mean annual precipitation for the 524 development of the paleosols of the Cerro Azul Formation is $449 \pm 147 \mathrm{~mm}$ (Cardonatto et al., 525 2016). Paleosols showing a Bt horizon and blocky or prismatic peds can be compared with 526 mollisols (Cardonatto et al., 2016). Some paleoenvironmental constraints can also be derived 527 from the composition of the mammal fauna, and the stable isotopic composition of enamel teeth. 528 Vertebrate remains of the Cerro Azul Formation, mainly notoungulates and rodents, suggest that 529 these sediments were deposited in open landscapes like steppes or herbaceous plains (Montalvo 530 et al., 2008). Carbon isotope composition from late Miocene herbivorous enamel teeth from

531 Salinas Grandes de Hidalgo and nearby localities indicates a dominance of C3 plants in lowland 532 areas (MacFadden, Cerling \& Prado, 1996), which are favoured in climates with cool growing 533 season (Ehleringer, Cerling \& Helliker, 1997)

\section{Orientation of burrows}

535 Comparison with orientation data from modern Dasypodidae burrows can help to interpret the 536 orientation pattern of fossil burrows. As xenarthrans are imperfect homeotherms, their body 537 temperatures do change with the environment (e.g., McNab, 1980, 1985). It has been suggested 538 that the burrow entrance orientation of armadillos avoid prevailing winds and both uniform and 539 preferential orientation has been documented (e.g., McDonough \& Loughry, 2008). The cases of 
540 no preferential orientation are related to the invasive armadillo Dasypus novemcinctus from

541 southern USA (Texas, Alabama, Oklahoma) and Belize (Clark, 1951; Zimmerman, 1990; Platt et

542 al., 2004; Sawyer et al., 2012). All these cases are mostly related to forested areas. Studies

543 documenting a preferred orientation of Dasypodidae burrows are from Argentina, Uruguay and

544 Brazil, involving open environments and several species (Crespo, 1944; Carter \& Encarnaçao,

545 1983; González, Soutullo \& Altuna, 2001; Abba, Udrizar \& Vizcaíno, 2005; Ceresoli \&

546 Fernandez Duque, 2012). The pioneer study by Crespo (1944) included three localities from

547 western Argentina, ranging from $27^{\circ} 37^{\prime} \mathrm{S}$ to $34^{\circ} 13^{\prime} \mathrm{S}$ and including annual precipitation

548 ranging from less than $200 \mathrm{~mm}$ to $500 \mathrm{~mm}$. The vegetation ranges from low bushes, to shrubland

549 and psammophilous grassland with sparse trees. These localities belong to the Monte and Espinal

550 biogeographic provinces (e.g., Roig, Roig-Juñent \& Corbalán, 2009) and the included armadillo

551 species are: Chaetophractus vellerosus, C. villosus and Zaedyus pichiy. A compilation of the

552 entrance orientation data from the three localities of Crespo (1944) suggests a dominant entrance

553 orientation toward the west (Fig. 9D). This distribution is remarkably similar to the fossil

554 burrows if we assume that entrance orientation was at $180^{\circ}$ of dipping azimuth (Fig. 9C).

555 Dominant surface wind patterns in northern Argentina are humid and sometimes hot winds from

556 the east and north (e.g., Barros et al., 2015), whereas cold winds are from the south. In

557 consequence, the orientation pattern described by Crespo (1944) from open environments of the

558 semiarid region of Argentina can be interpreted as preferential orientation of entrances avoiding

559 dominant hot and cold winds. Similar patterns of armadillo burrow entrance orientation avoiding

560 prevailing winds were documented by Carter \& Encarnaçao (1983) in Minas Gerais, Brazil;

561 González, Soutullo \& Altuna (2001) in Uruguay (Fig. 9E); Abba, Udrizar \& Vizcaíno (2005) in

562 Buenos Aires province of Argentina (Fig. 9F); and Ceresoli \& Fernández Duque (2012) in 
563 Formosa province, northern Argentina. Alternative explanations for this preferential orientation

564 are that, as the armadillos seek food following an odour in the wind, they tend to approach a site

565 from downwind and dig in the lee side (Carter \& Encarnaçao, 1983) and to maximize sun

566 exposure during cold winters (Ceresoli \& Fernández Duque, 2012). In particular, the most

567 adequate example to evaluate the orientation of the fossil burrows is the data from dasypodid

568 burrows by Crespo (1944), which were collected in open semiarid settings similar to those of the

569 late Miocene of central Argentina. In consequence, it is possible to propose that the late Miocene

570 wind pattern of central Argentina was similar to the present one with hot winds from the east and

571 north and cold winds from the south.

572 Associated trace fossils

573 The trace fossil assemblage of the Cerro Azul Formation is of low diversity and abundance and

574 dominated by insect trace fossils (Celliforma, Rosellichnus, Fictovichnus, Rebuffoichnus and

575 Teisseirei), and was compared with the Celliforma ichnofacies (Cardonatto et al., 2016). The

576 Celliforma ichnofacies is typical of well-drained calcareous paleosols developed under low

577 vegetation coverage (Genise et al., 2010, 2016). The reduced size of associated rhizoliths

578 suggests that the vegetation was dominated by scrubs with minor participation of herbaceous

579 plants.

580 The local occurrence of cemented Coprinisphaera at LLP and additional occurrences of fossil

581 dung-beetle brood balls (Quirogaichnus coniunctus Laza, 2006) from the formation in a nearby

582 locality (Laza, 2006) is indicative of the presence of the Coprinisphaera ichnofacies, suggesting

583 herbaceous communities and wetter climatic conditions (Genise et al., 2016) for the easternmost

584 locations of the formation. 
585 Burrowing habits in large late Miocene mammals

586 Mammal burrows are typically constructed as shelters from environmental extremes and

587 predators, and also for food storage, foraging and reproduction (e.g., Reichman \& Smith, 1990;

588 Kinlaw, 1999). From these common uses of burrows, protection from environmental extremes

589 and predators are more likely for the studied fossil burrows and no evidence supporting the

590 remaining functions is available. Top predators during deposition of the Cerro Azul Formation

591 are the Phorusrhacidae (Cenizo, Tambussi \& Montalvo, 2012; Vezzosi, 2012) that occupied the

592 role of large carnivorans, as well as the Sparassodonta (Goin, Montalvo \& Visconti, 2000).

593 However, the main factor controlling the occurrence of large mammal burrows during the late

594 Miocene (Fig. 1) is herein related to environmental changes. It has been suggested that different

595 mammal groups acquired fossorial habits during the Cenozoic as a response to the expansion of

596 open, savanna-like environments under cold, dry and seasonal climates (Nevo, 1979; 1995;

597 2011). During the late Miocene (the Huayquerian SALMA), southern South America

598 experienced a global cooling as response to the increase in the Antarctic ice sheet (Zachos et al.,

599 2001) and the uplift of the Andes (e.g., Amidon et al., 2017), which favored cold and seasonally

600 dry climatic conditions. This regional framework is confirmed by the inferences on the

601 sedimentology, faunal remains and invertebrate ichnology of the studied succession. This

602 evidence suggests open environments, with well-drained soils and low vegetation coverage, and

603 a semiarid and seasonal climate. Considering that the more likely candidates for the largest

604 burrows are xenarthrans (Glyptodontidae and Mylodontidae), which are imperfect homeotherms

605 (e.g., McNab, 1980; 1985), the necessity and convenience for excavating an underground refuge

606 is clear. In addition to escape from predation, these animals used burrows to avoid extremely

607 cold or warm climatic conditions in order to conserve energy and water, and to breed because of

608 the particular physiology of xenarthrans (Vizcaíno et al., 2001). 


\section{Conclusions}

610 Subcylindrical structures with a laminated fill occurring in a late Miocene loess-paleosol

611 sequence from central Argentina are interpreted as burrows of fossorial mammals. The burrows

612 occur associated with calcareous paleosols developed under a semiarid climate in a flat

613 landscape. A detailed analysis of more than one hundred structures permitted to conclude that:

614 1. The more common geometry is a shallow ramp with a rounded end, lacking bifurcations.

615 2. The ample variation of the horizontal diameter of the burrows, along with cross-sectional

616 shape and inferred body masses suggest that several producers were involved.

617 3. The smaller burrows ( $\mathrm{Dh}=0.15-0.34 \mathrm{~m}, 8 \%$ of cases, body mass ranging from 1 to $13 \mathrm{~kg})$

618 were produced by small dasypodids and, secondarily, by the notoungulate Paedotherium minor.

619 4. For the dominant burrows exhibiting an intermediate $(\mathrm{Dh}=0.39-0.94 \mathrm{~m}, 83 \%$ of measured

620 burrows, producer body mass of 37 to $438 \mathrm{~kg}$ ), and large horizontal diameter ( $\mathrm{Dh}=1.05-1.50 \mathrm{~m}$,

$6219 \%$ of measured burrows, producer body mass of $700-1600 \mathrm{~kg}$ ), the Glyptodontidae and

622 Mylodontidae (Proscelidodon sp.) are the best candidates. The Glyptodontidae are related to the

623 subcircular burrows of intermediate size and Proscelidodon sp. would be the producer of the

624 elliptical and largest burrows.

6255 . About $10 \%$ of the burrow fills contained fragmentary, disarticulated, abraded and weathered

626 bone remains that were introduced into the burrows by aqueous currents and do not belong to the

627 excavator of the burrow.

628 6. After abandonment, the burrows received sediments from the surface that progressively filled

629 the structure. The filling process was produced dominantly by several pulses of sediment laden

630 currents related to moderate rains (well laminated fill) and en masse input of dense sediment-

631 laden currents related to heavy rains producing sheet flooding (massive fill). During filling, the

632 abandoned burrows were visited or reoccupied by other tetrapods and used by bees to nest, 
633 7. It is not considered likely that well laminated burrow fills will contain remains of the

634 producer, whereas massive fills have a greater chance of containing remains of the tetrapod that

635 dug the burrow.

636 8. The main factor explaining the appearance of large mammal burrows in the late Miocene are

637 environmental changes, including open environments with low vegetation and semiarid and

638 seasonal climate.

639

640 Acknowledgements

641 We are indebted to Fátima Mendoza Belmontes for help during field work, Claudia Montalvo for

642 guidance with the taxonomy of vertebrate remains and for appropriate comments on an earlier version of

643 the manuscript, Marcelo Zárate for noticing about the fossil burrows of the LLP locality, Ricardo Bonini

644 for field permit, and María F. Vera Candioti for help on morphometric analysis.

645

646

647 References

648 Abba AM, Udrizar DE, Vizcaíno, SF. 2005. Distribution and use of burrows and tunnels of 649 Chaetophractus villosus (Mammalia, Xenarthra) in the eastern Argentinean pampas. Acta 650 Theriologica, 50: 115-124.

651 Amidon WH, Fisher GB, Burbank DW, Ciccioli PL, Alonso RN, Gorin AL, Silverhart PH, 652 Kylander-Clark ARC, Christoffersen MS. 2017. Mio-Pliocene aridity in the south-central Andes 653 associated with Southern Hemisphere cold periods. Proceedings of the National Academy of 654 Sciences, 114: 6474-6479.

655 Aramayo SA. 1988. Nuevos restos de Proscelidodon sp. (Edentata, Mylodontidae) del 656 Yacimiento Monte Hermoso (Plioceno inferior a medio) provincia de Buenos Aires, Argentina. 657 Estudio morfológico funcional. Actas Segundas Jornadas Geológicas Bonaerenses: 99-107.

658 Barbour EH. 1892. Notice of new gigantic fossils. Science N.S. 19: 99-100.

659 Bargo MS, Vizcaíno SF, Archuby FM, Blanco, RE. 2000. Limb bone proportions, strength and 660 digging in some Lujanian (Late Pleistocene-Early Holocene) mylodontid ground sloths

661 (Mammalia, Xenarthra). Journal of Vertebrate Paleontology, 20: 601-610. 
662 Barros VR, Boninsegna JA, Camilloni IA, Chidiak M, Magrín GO, Rusticucci M. 2015. Climate

663 change in Argentina: trends, projections, impacts and adaptation. Wiley Interdisciplinary

664 Reviews: Climate Change, 6: 151-169.

665 Benton MJ. 1988. Burrowing by vertebrates. Nature, 331: 17-18.

666 Bown TM. 1982. Ichnofossils and rhizoliths of the nearshore fluvial Jebel Qatrani Formation

667 (Oligocene), Fayum Province, Egypt. Palaeogeography, Palaeoclimatology, Palaeoecology, 40:

$668 \quad 255-309$.

669 Bown TM, Kraus MJ. 1983. Ichnofossils of the alluvial Willwood Formation (lower Eocene),

670 Bighorn Basin, northwest Wyoming, U.S.A. Palaeogeography, Palaeoclimatology,

671 Palaeoecology, 43: 95-128.

672 Buchmann FS, Pereira Lopez R, Caron F. 2009. Icnofósseis (paleotocas e crotovinas) atribuídos a

673 mamíferos extintos no sudeste e sul do Brasil. Revista brasileira paleontological, 12: 247-256.

674 Cabrera A. 1939. Sobre vertebrados fósiles del Plioceno de Adolfo Alsina. Rev. Mus. de La Plata

675 (Nueva Serie), 2: 3-35.

676 Cardonatto MC, Sostillo R, Visconti G, Melchor RN. 2016. The Celliforma ichnofacies in

677 calcareous paleosols: An example from the late Miocene Cerro Azul Formation, La Pampa,

678 Argentina. Palaeogeography, Palaeoclimatology, Palaeoecology, 443: 203-215.

679 Carter TS, Encarnaçao CD. 1983. Characteristics and use of burrows by four species of

680 armadillos in Brazil. Journal of Mammalogy, 64: 103-108.

681 Cenizo MM, Tambussi CP, Montalvo CI. 2012. Late Miocene continental birds from the Cerro

682 Azul Formation in the Pampean region (central-southern Argentina). Alcheringa, 36: 47-68.

683 Cerdeño E, Montalvo CI. 2001. Los Mesotheriinae (Mesotheriidae, Notoungulata) del Mioceno 684 superior de La Pampa, Argentina. Revista Española de Paleontología, 16: 63-75.

685 Ceresoli N, Fernandez-Duque E. 2012. Size and orientation of giant armadillo burrow entrances 686 (Priodontes maximus) in western Formosa Province, Argentina. Edentata, 13: 66-68.

687 Cione AL, Azpelicueta, MM, Bond M, Carlini AA, Casciotta JR, Cozzuol MA, de la Fuente M, 688 Gasparini Z, Goin FJ, Noriega J, Scillato-Yané GJ, Soibelzon L, Tonni EP, Verzi D, Vucetich 689 MG. 2000. Miocene vertebrates from Entre Ríos province, eastern Argentina. En: F.G.

690 Aceñolaza y R. Herbst (Eds.), El Neógeno de Argentina. Serie Correlación Geológica, 14: 191691237.

692 Clark WK. 1951. Ecological life history of the armadillo in the eastern Edwards Plateau region. 693 American Midland Naturalist, 46: 337-58.

694 Crespo J. 1944. Contribución al conocimiento de la ecología de algunos dasipódidos (Edentata) 695 Argentinos. Revista Argentina de Zoogeografía, Buenos Aires, 4: 7-39.

696 Croft DA, Flynn JJ, Wyss, A. 2004. Notoungulata and Litopterna of the early Miocene Chucal

697 Fauna, northern Chile. Fieldiana, Geology, n.s. 50, 1-52.

698 Damiani R, Modesto S, Yates A, Neveling J. 2003. Earliest evidence of cynodont burrowing.

699 Proceedings of the Royal Society of London B: Biological Sciences, 270: 1747-1751. 
700 De Esteban-Trivigno S, Mendoza M, De Renzi M . 2008. Body mass estimation in Xenarthra: A 701 predictive equation suitable for all quadrupedal terrestrial placentals? Journal of Morphology, 702 269: 1276-1293.

703 De Elorriaga EE, Visconti G. 2002. Crotovinas atribuibles a grandes mamíferos del Cenozoico

704 en el sureste de la Provincia de La Pampa. $9^{\circ}$ Reunión Argentina de Sedimentología, Resúmenes, 705 Asociación Argentina de Sedimentología, Córdoba: 63.

706 Delsuc F, Superina M, Tilak M, Douzery EJP, Hassanin A. 2012. Molecular phylogenetics

707 unveils the ancient evolutionary origins of the enigmatic fairy armadillos. Molecular

708 Phylogenetics and Evolution, 62: 673-80

709 Dondas A, Isla FI, Carballido JL. 2009. Paleocaves exhumed from the Miramar Formation

710 (Ensenadan Stage-age, Pleistocene), Mar del Plata, Argentina. Quaternary International, 210: 4471150.

712 Duarte RG. 1997. Gliptodontes del Pleistoceno tardío de Agua de las Palomas, Campo del

713 Pucará, Catamarca, Argentina. Variaciones morfológicas del caparazón de Glyptodon reticulatus

714 Owen, 1845. Ameghiniana, 34: 345-355.

715 Ehleringer JR, Cerling TE, Helliker BR. 1997. C4 photosynthesis, atmospheric CO2, and 716 climate. Oecologia, 112: 285-299.

717 Elissamburu A. 2004. Análisis morfométrico y morfofuncional del esqueleto apendicular de

718 Paedotherium (Mammalia, Notoungulata). Ameghiniana, 41: 363-380.

719 Elissamburu A, Dondas A, De Santis L. 2011. Morfometría de las paleocuevas de la "Fm." 720 Chapadmalal y su asignación a Actenomys (Rodentia), Paedotherium (Notoungulata) y otros 721 mamíferos fósiles hospedantes. Mastozoología Neotropical, 18: 227-238.

722 Fariña RA, Vizcaíno SF, Bargo MS. 1998. Body mass estimations in Lujanian (late Pleistocene723 early Holocene of South America) mammal megafauna. Mastozoología Neotropical, 5: 87-108.

724 Fernández ME, Vassallo AI, Zárate M. 2000. Functional morphology and paleobiology of the 725 Pliocene rodent Actenomys (Caviomorpha: Octodontidae): the evolution to a subterranean mode 726 of life. Biological Journal of the Linnean Society, 71:71-90.

727 Frank HT, Buchmann FS, Gonçalves de Lima L, Fornari M, Caron F. 2012. Cenozoic vertebrate 728 tunnels in southern Brazil. In: Netto RG, Carmona NB, Tognoli, FM (Eds.), Ichnology of Latin 729 America: selected papers, Monografías da Sociedade Brasileira de Paleontología, 2: 141-158.

730 Frank HT, Althaus CE, Dario EM, Tramontina FR, Adriano RM, Almeida ML, Ferreira GF, 731 Nogueira R, Breier R. 2015. Underground chamber systems excavated by Cenozoic ground 732 sloths in the state of Rio Grande do Sul, Brazil. Revista Brasileira de Paleontologia, 18: 273-284.

733 Frenguelli J. 1955. Loess y limos pampeanos. Universidad Nacional de La Plata, Facultad de 734 Ciencias Naturales y Museo, Serie técnica y didáctica, 7:1-88.

735 Folguera A, Zárate M. 2009. La sedimentación neógena continental en el sector extrandino de 736 Argentina central. Revista de la Asociación Geológica Argentina, 64: 692-712.

737 Gee CT, Sander PM, Petzelberger BEM. 2003. A Miocene rodent nut cache in coastal dunes of 738 the Lower Rhine Embayment, Germany. Palaeontology, 46: 1133-1149. 
739 Genise JF. 1989. Las cuevas de Actenomys (Rodentia: Octodontidae) de la Formación

740 Chapadmalal (PIioceno superior) de Mar del Plata y Miramar (Provincia de Buenos Aires).

741 Ameghiniana, 26: 33-42.

742 Genise JF, Farina JL. 2012. Ants and xenarthrans involved in a Quaternary food web from

743 Argentina as reflected by their fossil nests and palaeocaves. Lethaia, 45: 411-422.

744 Genise JF, Melchor RN, Bellosi ES, Verde M. 2010. Invertebrate and vertebrate trace fossils

745 from continental carbonates. In: Alonso-Zarza AM, Tanner L, Carbonates in continental settings:

746 facies, environments and processes, Developments in Sedimentology, 61: 319-369.

747 Genise JF, Melchor RN, Sánchez MV, González MG. 2013. Attaichnus kuenzelii revisited: A

748 Miocene record of fungus-growing ants from Argentina. Palaeogeography, Palaeoclimatology,

749 Palaeoecology, 386: 349-363.

750 Genise JF, Bedatou E, Bellosi E, Sarzetti LC, Sánchez MV, Krause JM. 2016. The Phanerozoic

751 four revolutions and evolution of paleosol ichnofacies. In: LA Buatois, Mángano MG, The trace-

752 fossil record of major evolutionary events. p. 301-370.

753 Gobetz KE, Martin LD. 2006. Burrows of a gopher-like rodent, possibly Gregorymys

754 (Geomyoidea: Geomyidae: Entoptychtinae), from the early Miocene Harrison Formation,

755 Nebraska. Palaeogeography, Palaeoclimatology, Palaeoecology, 237: 305-314.

756 Goin FJ, Montalvo CI, Visconti G. 2000. Los marsupiales (Mammalia) del Mioceno Superior de

757 la Formación Cerro Azul (Provincia de La Pampa, Argentina). Estudios Geológicos, 56: 101-

758126.

759 González EM, Soutullo A, Altuna CA. 2001. The burrow of Dasypus hybridus (Cingulata:

760 Dasypodidae). Acta Theriologica, 46: 53-59.

761 Groenewald GH, Welman J, MacEachern JA. 2001. Vertebrate burrow complexes from the Early

762 Triassic Cynognathus Zone (Driekoppen Formation, Beaufort Group) of the Karoo Basin, South

763 Africa. Palaios, 16: 148-160.

764 Hembree DI, Martin LD, Hasiotis ST. 2004. Amphibian burrows and ephemeral ponds of the

765 Lower Permian Speiser Shale, Kansas: evidence for seasonality in the midcontinent.

766 Palaeogeography, Palaeoclimatology, Palaeoecology, 203: 127-152.

767 Hembree DI, Hasiotis ST. 2008. Miocene vertebrate and invertebrate burrows defining

768 compound paleosols in the Pawnee Creek Formation, Colorado, U.S.A. Palaeogeography,

769 Palaeoclimatology, Palaeoecology, 270: 349-365.

770 Hunt RM. 1990. Taphonomy and sedimentology of Arikaree (lower Miocene) fluvial, eolian, and

771 lacustrine paleoenvironments, Nebraska and Wyoming: A paleobiota entombed in fine-grained

772 volcaniclastic rocks. In: Lockley MG, Rice A, Volcanism and fossil biotas. Geological Society

773 of America, Special Paper, 244: 69-111.

774 Hunt RMJ, Xiang-Xu XUE, Kaufman J. 1983. Miocene burrows of extinct bear dogs: Indication

775 of early denning behavior of large mammalian carnivores. Science, 221: 364-366.

776 Imbellone P, Teruggi M, Mormeneo L. 1990. Crotovinas en sedimentos cuaternarios del partido

777 de la Plata. In: Zárate M. (Ed.) Simposio Internacional sobre Loess, pp. 166-172. Mar del Plata. 
778 Jackson JE, Branch LC, Villarreal D. 1996. Lagostomus maximus. Mammalian Species, 543: 17796.

780 Johnson SY. 1989. Significance of loessite in the Maroon Formation (Middle Pennsylvanian to

781 Lower Permian), Eagle Basin, Northwest Colorado. Journal of Sedimentary Research, 59: 782782791.

783 Kinlaw A. 1999. A review of burrowing by semi-fossorial vertebrates in arid environments.

784 Journal of Arid Environments, 41: 127-145.

785 Kraglievich L. 1934. La antigüedad pliocena de las faunas de Monte Hermoso y Chapadmalal,

786 deducidas de su comparación con las que le precedieron y sucedieron. Imprenta "El Siglo

787 Ilustrado", $136 \mathrm{p}$.

788 Krummeck WD, Bordy EM. 2017. Reniformichnus katikatii (new ichnogenus and ichnospecies):

789 Continental vertebrate burrows from the Lower Triassic, Main Karoo Basin, South Africa.

790 Ichnos, 24: 1-12 (in press)

791 Laza, JH. 2006. Dung-beetle fossil brood balls: The ichnogenera Coprinisphaera Sauer and

792 Quirogaichnus (Coprinisphaeridae). Ichnos, 13: 217-235.

793 Linares E, Llambías E, Latorre C. 1980. Geología de la Provincia de La Pampa, República

794 Argentina y Geocronología de sus rocas metamórficas y eruptivas. Revista de la Asociación

795 Geológica Argentina, 35: 87-146.

796 Liu J, Li L. 2013. Large tetrapod burrows from the Permian Naobaogou Formation of the

797 Daqingshan Area, Nei Mongol, China. Acta Geologica Sinica - English Edition, 87: 1501-1507.

798 Llanos AC, Crespo JA. 1952. Ecología de la vizcacha (Lagostomus maximus maximus Blainv.)

799 en el nordeste de la provincia de Entre Ríos. Revista de Investigaciones Agrícolas, 6:289-378.

800 Loope DB. 2006. Burrows dug by large vertebrates into rain-moistened Middle Jurassic sand 801 dunes. Journal of Geology. 114: 753-762.

802 Loope DB. 2008. Life beneath the surfaces of active Jurassic dunes: Burrows from the Entrada

803 Sandstone of south-central Utah. Palaios, 23: 411-419.

804 Lorenzo FR, Mehl AE, Zárate MA. 2013. Sedimentología y estratigrafía de depósitos del

805 Mioceno tardío de los valles transversales de la provincia de La Pampa, Argentina. Latin

806 American Journal of Sedimentology and Basin Analysis, 20: 67-84.

807 Lucas SG, Gobetz KE, Odier GP, McCormick T, Egan C. 2006. Tetrapod burrows from the

808 Lower Jurassic Navajo Sandstones, southeastern Utah. In: JD Harris, Lucas SG, Spielmann JA,

809 Lockley MG, Milner ARC, Kirkland JI (Eds), The Triassic-Jurassic Terrestrial Transition New

810 Mexico Museum of Natural History and Science Bulletin, 37: 147-154.

811 MacFadden BJ, Cerling TE, Prado J. 1996. Cenozoic terrestrial ecosystem evolution in

812 Argentina: Evidence from carbon isotopes of fossil mammal teeth. Palaios, 11: 319-327.

813 Major JJ. 1997. Depositional processes in large-scale debris-flow experiments. Journal of

814 Geology, 106: 345-366.

815 Martin LD, Bennett DK. 1977. The burrows of the Miocene beaver Palaeocastor, Western

816 Nebraska, U.S.A. Palaeogeography, Palaeoclimatology, Palaeoecology,. 22: 173-193. 
817 McDonald HG. 1987. A systematic review of the Plio-Pleistocene Scelidotherinae Ground Sloth

818 (Mammalia: Xenarthra: Mylodontidae). PhD Tesis, University of Toronto, Toronto, Canada, 478

819 p. Unpublished.

820 McDonald HG, Perea D. 2002. The large Scelidothere Catonyx tarijensis (Xenarthra,

821 Mylodontidae) from the Pleistocene of Uruguay. Journal of Vertebrate Paleontology, 22: 677-

822683.

823 McDonough CM, Loughry WJ. 2008. Behavioral ecology of armadillos. In: Vizcaíno SF,

824 Loughry WJ (Eds), The Biology of Xenarthra, p. 281-293. Gainesville.

825 Macleod N .2009. Who is Procrustes and what has he done with my data. Palaeontological

826 Association Newsletter, 70: 21-36.

827 McNab BK. 1980. Energetics and the limits to a temperate distribution in armadillos. Journal of 828 Mammalogy, 61: 606-27.

829 McNab BK.1985. Energetics, population biology, and distribution of xenarthrans, living and

830 extinct. In Montgomery GG (Ed), The evolution and ecology of armadillos, sloths and

831 vermilinguas, p. 219-232. Smithsonian Institution Press, Washington, D.C.

832 Melchor RN, Casadío S. 2000. Descripción Geológica de la Hoja 3766-III "La Reforma"

833 (1:250.000), Provincia de la Pampa. Servicio Geológico Minero Argentino, Boletín, 295: 1-56.

834 Melchor RN, Bedatou E, de Valais S, Genise JF. 2006. Lithofacies distribution of invertebrate 835 and vertebrate trace-fossil assemblages in an Early Mesozoic ephemeral fluvio-lacustrine system

836 from Argentina: Implications for the Scoyenia ichnofacies. Palaeogeography, Palaeoclimatology,

837 Palaeoecology, 239: 253-285.

838 Melchor RN, Genise JF, Umazano AM, Superina M. 2012. Pink fairy armadillo meniscate

839 burrows and ichnofabrics from Miocene and Holocene interdune deposits of Argentina:

840 Palaeoenvironmental and palaeoecological significance. Palaeogeography, Palaeoclimatology,

841 Palaeoecology, 350-352: 149-170.

842 Melchor RN, Loope D. 2016. Communal therapsid burrows from interdune facies of the Lower

843 Jurassic Navajo Sandstone, southern Utah, USA. Abstract book Ichnia: 174.

844 Miño Boilini AR, Tomassini RL, Oliva C, Manera de Bianco T. 2011. Adiciones al

845 conocimiento de Proscelidodon Bordas, 1935 (Mammalia, Xenarthra, Scelidotheriinae). Revista

846 Brasileira de Paleontologia, 14: 269-278.

847 Montalvo CI, Casadío S. 1988. Presencia del género Palaeoctodon (Rodentia, Octodontidae) en 848 el Huayqueriense (Mioceno tardío) de la Provincia de La Pampa. Ameghiniana, 25: 111-114.

849 Montalvo CI, Visconti G, Púgener L, Cardonatto MC. 1995. Mamíferos de Edad Huayqueriense

850 (Mioceno tardío), Laguna Chillhué, provincia de La Pampa. $4^{\circ}$ Jornadas Geológicas y Geofísicas 851 Bonaerenses (Junín), Actas 1: 73-79.

852 Montalvo CI, Melchor RN, Visconti G, Cerdeño E. 2008. Vertebrate taphonomy in loess-

853 palaeosol deposits: A case study from the late Miocene of central Argentina. Geobios, 41: 133854143.

855 Montalvo CI, Tomassini RL, Sostillo R. 2016. Leftover prey remains: a new taphonomic mode

856 from the late Miocene (Cerro Azul Formation) in central Argentina. Lethaia, 49: 219-230. 
857 Modesto SP, Botha Brink J. 2010. A burrow cast with Lystrosaurus skeletal remains from the

858 Lower Triassic of South Africa. Palaios, 25: 274-281.

859 Nevo E. 1979. Adaptive convergence and divergence of subterranean mammals. Annual Review 860 of Ecology and Systematics, 10: 269-308.

861 Nevo E. 1995. Mammalian evolution underground. The ecological-genetic-fenetic interfaces.

862 Acta Theriologica, 3: 9-31.

863 Nevo E. 2011. Evolution under environmental stress at macro- and microscales. Genome

864 Biology and Evolution, 3: 1039-1052.

865 Ortiz Jaureguizar E. 1998. Paleoecología y evolución de la fauna de mamíferos de América del

866 Sur durante la "Edad de las Planicies Australes" (Mioceno superior-Plioceno superior). Estudios

867 Geológicos, 54: 161-169.

868 Perea D. 2005. Pseudoplohophorus absolutus n. sp. (Xenarthra, Glyptodontidae), variabilidad en

869 Sclerocalyptinae y redefinición de una biozona del Mioceno Superior de Uruguay. Ameghiniana, 870 42: 175-190.

871 Perea D, Scillato-Yané GJ. 1995. Proeuphractus limpidus Ameghino, 1886 (Xenarthra,

872 Dasypodidae, Euphractini): Osteología comparada del cráneo y elementos de la coraza asociados

873 (Neógeno del Uruguay). Boletín de la Real Sociedad Española de Historia Natural, 90: 125-130.

874 Platt SG, Rainwater TR, Brewer SW. 2004. Aspects of the burrowing ecology of nine-banded

875 armadillos in northern Belize. Mammalian Biology, 69: 217-224.

876 Pujos F, Candela A, Galli CI, Coira BL, Reguero MA, de los Reyes M, Abello MA. 2012. The

877 Scelidotheriine Proscelidodon (Xenarthra: Mylodontidae) from the Late Miocene of Maimará

878 (Northwestern Argentina, Jujuy Province). Ameghiniana, 49: 668-674.

879 Pye K. 1995. The nature, origin and accumulation of loess. Quaternary Science Reviews, 14:

$880 \quad 653-667$.

881 Quintana CA. 1992. Estructura interna de una paleocueva, posiblemente de un Dasypodidae

882 (Mammalia, Edentata) del Pleistoceno de Mar del Plata (Provincia de Buenos Aires, Argentina).

883 Ameghiniana, 29: 87-91.

884 Rafuse DJ, Kaufmann CA, Gutiérrez MA, González ME, Scheifler NA, Álvarez MC, Massigoge 885 A. 2017. Taphonomy of modern communal burrow systems of the Plains vizcacha (Lagostomus

886 maximus, Chinchillidae) in the Pampas region of Argentina: implications for the fossil record.

887 Historical Biology:1-17 (in press).

888 Reichman OJ, Smith SC. 1990. Burrows and burrowing behavior by mammals. Current

889 Mammalogy, 2: 197-244.

890 Riese DJ, Hasiotis ST, Odier GP. 2011. Synapsid burrows and associated trace fossils in the

891 lower Jurassic Navajo Sandstone, Southeastern Utah, U.S.A., indicates a diverse community

892 living in a wet desert ecosystem. Journal of Sedimentary Research, 81: 299-325.

893 Roig FA, Roig-Juñent S, Corbalán V. 2009. Biogeography of the Monte Desert. Journal of Arid 894 Environments, 73: 164-172.

895 Rovereto C. 1914. Los estratos araucanos y sus fósiles. Anales del Museo Nacional de Historia

896 Natural de Buenos Aires, 25: 1-247. 
897 Sawyer CF, Brinkman DC, Walker VD, Covington TD, Stienstraw EA. 2012. The

898 zoogeomorphic characteristics of burrows and burrowing by nine-banded armadillos (Dasypus

899 novemcinctus). Geomorphology, 157: 122-130.

900 Scognamillo DG. 1993. Estructura de las cuevas de Actenomys (Rodentia: Octodontidae) de la

901 Aloformación Playa San Carlos, Plioceno tardío (Barranca de los Lobos, Pdo. Gral. Pueyrredón):

902 significado paleoecológico y estratigráfico. Unpublished Licenciate thesis, National University

903 of Mar del Plata, Argentina, 32 pp.

904 Scillato-Yané GJ. 1982. Los Dasypodidae (Mammalia-Edentata) del Plioceno y Pleistoceno de

905 Argentina. Tesis Doctoral. Facultad de Ciencias Naturales y Museo, Universidad Nacional de La 906 Plata, 159 pp. Inédita.

907 Scillato-Yané GJ, Krmpotic CM, Esteban GI. 2010. The species of genus Chasicotatus Scillato-

908 Yané (Eutatini, Dasypodidae). Revista Mexicana de Ciencias Geológicas, 27: 43-55.

909 Scillato -Yané G, Góis F, Zurita AE, Carlini A, González Ruiz L, Krmpotic C, Oliva C,

910 Zamorano M. 2013. Los Cingulata (Mammalia, Xenarthra) del "Conglomerado osífero"

911 (Mioceno Tardío) de la Formación Ituzaingó de Entre Ríos, Argentina. Asociación

912 Paleontológica Argentina, Publicación Especial, 14: 118-134.

913 Seilacher A. 2007. Trace Fossil Analysis. Berlin: Springer, 226 p.

914 Sheldon ND, Tabor NJ. 2009. Quantitative paleoenvironmental and paleoclimatic reconstruction

915 using paleosols. Earth-Science Reviews, 95: 1-52.

916 Shockey BJ, Croft DA, Anaya F. 2007. Analysis of function in the absence of extant functional

917 homologues: a case study using mesotheriid notoungulates (Mammalia). Paleobiology, 33: 227-

918247.

919 Sidor CA, Miller MF, Isbell JL. 2008. Tetrapod burrows from the Triassic of Antarctica. Journal 920 Vertebrate Paleontology, 28: 277-284.

921 Slice DE, Bookstein FL, Marcus LF, Rohlf FJ. 2008. A Glossary for Geometric Morphometrics

922 web site: http://life.bio.sunysb.edu/morph/.

923 Smith R. 1987. Helical burrow casts of therapsid origin from the Beaufort Group (Permian) of

924 South Africa. Palaeogeography, Palaeoclimatology, Palaeoecology, 60: 155-170.

925 Soibelzon LH, Pomi LH, Tonni EP, Rodriguez S, Dondas A. 2009. First report of a South

926 American short-faced bears' den (Arctotherium angustidens): palaeobiological and

927 palaeoecological implications. Alcheringa, 33: 211-222.

928 Taglioretti M, Miño-Boilini AR, Scaglia F, Dondas A. 2014. Presencia de Proscelidodon patrius

929 (Xenarthra, Scelidotheriinae) en la Formación Chapadmalal (Plioceno superior), Mar del Plata,

930 Buenos Aires, Argentina: Implicancias bioestratigráficas. Ameghiniana, 51: 420-427.

931 Torres MR, Borghi CE, Giannoni SM, Pattini, A. 2003. Portal orientation and architecture of

932 burrows in Tympanoctomys barrerae (Rodentia, Octodontidae). Journal of Mammalogy, 84:

$933541-546$.

934 Urrutia JJ, Montalvo CI, Scilato-Yané GJ. 2008. Dasypodidae (Xenarthra, Cingulata) de la

935 Formación Cerro Azul (Mioceno tardío) de la provincia de La Pampa, Argentina. Ameghiniana,

936 45: 289-302. 
937 Varricchio DJ, Martin AJ, Katsura Y. 2007. First trace and body fossil evidence of a burrowing,

938 denning dinosaur. Proceedings of the Royal Society B: Biological Sciences, 274: 1361-1368.

939 Verzi DH, Montalvo CI, Vucetich MG. 1999. Afinidades y significado evolutivo de

940 Neophanomys biplicatus (Rodentia, Octodontidae) del Mioceno tardío-Plioceno temprano de

941 Argentina. Ameghiniana, 36: 83-90.

942 Verzi DH, Montalvo CI, Tiranti SI. 2003. Un nuevo Xenodontomys (Rodentia, Octodontidae) del

943 Mioceno tardío de La Pampa, Argentina. Patrón evolutivo y bioestratigrafía. Ameghiniana, 40:

944 229-238.

945 Verzi DH, Montalvo CI, Deschamps C. 2008. Biostratigraphy and biochronology of the Late

946 Miocene of central Argentina: evidence from rodents and taphonomy. Geobios, 41: 145-155.

947 Vezzosi RI. 2012. First record of Procariama simplex Rovereto, 1914 (Phorusrhacidae,

948 Psilopterinae) in the Cerro Azul Formation (upper Miocene) of La Pampa Province; remarks on

949 its anatomy, palaeogeography and chronological range. Alcheringa, 36: 157-169.

950 Visconti G. 2007. Sedimentología de la Formación Cerro Azul (Mioceno superior) de la

951 provincia de La Pampa. Tesis doctoral inédita. Biblioteca de la Facultad de Ciencias Exactas y

952 Naturales de la UBA "Luis Federico Leloir". 203 p.

953 Visconti G, Melchor RN, Montalvo CI, Umazano AM, de Elorriaga EE. 2010. Análisis

954 litoestratigráfico de la Formación Cerro Azul (Mioceno superior) en la provincia de La Pampa.

955 Revista de la Asociación Geológica Argentina, 67: 257-265.

956 Vizcaíno SF, Fariña RA. 1999. On the flight capabilities and distribution of the giant Miocene

957 bird Argentavis magnificens (Teratornithidae). Lethaia, 32: 271-278.

958 Vizcaíno SF, Zárate M, Bargo MS, Dondas A. 2001. Pleistocene burrows in the Mar del Plata

959 area (Argentina) and their probable builders. Acta Palaeontologica Polonica, 46 (2): 289-301.

960 Vizcaíno SF, Blanco RE, Bender JB, Milne N. 2011. Proportions and function of the limbs of

961 glyptodonts. Lethaia, 44: 93-101.

962 Vogt T, Carballo OC, Calmels AP. 1999. Un esbozo de explicación de la génesis de las toscas de

963 la meseta de La Pampa. $1^{\circ}$ Congreso Argentino de Cuaternario y Geomorfología, Actas: 195-

964205.

965 Voorhies MR. 1975. Vertebrate burrows. In: Frey RW (Ed.), The study of trace fossils. p. 325-

966 350. New York.

967 Woodruff DC, Varricchio DJ. 2011. Experimental modeling of a possible Oryctodromeus

968 cubicularis (Dinosauria) burrow. Palaios, 26: 140-151.

969 Wu NC, Alton LA, Clemente CJ, Kearney MR, White CR. 2015. Morphology and burrowing

970 energetics of semi-fossorial skinks (Liopholis spp.). The Journal of Experimental Biology, 218:

971 2416-2426.

972 Zachos J, Pagani M, Sloan L, Thomas E, Billups K. 2001. Trends, rhythms, and aberrations in

973 global climate 65 Ma to Present. Science, 292: 686-693.

974 Zárate MA, Bargo MS, Vizcaíno SF, Dondas A, Scaglia O. 1998. Estructuras biogénicas en el

975 Cenozoico tardío de Mar del Plata (Argentina) atribuibles a grandes mamíferos. Revista

976 Asociación Argentina de Sedimentología, 5: 95-103. 
977 Zimmerman JW. 1990. Burrow characteristics of the nine-banded armadillo, Dasypus

978 novemcinctus. Southwestern Naturalist, 35: 226-27.

979 Zurita AE, Soibelzon LH, Soibelzon E, Gasparini GM, Cenizo MM, Arzani H. 2010. Accessory

980 protection structures in Glyptodon Owen (Xenarthra, Cingulata, Glyptodontidae). Annales de

981 Paléontologie, 96: 1-11.

982 Zurita AE, Oliva C, Dondas A, Soibelzon E, Isla FI. 2011. El registro más completo de un

983 Hoplophorini (Xenarthra: Glyptodontidae) para los Pisos/Edades Chapadmalalense-Marplatense

984 (Plioceno tardío-Pleistoceno temprano). Revista del Museo Argentino de Ciencias Naturales, 13:

985 69-75.

986

987

\section{Legend of figures}

989 Figure 1. Plot of the average horizontal diameter (Dh) of tetrapod burrows in the published

990 literature against the age of the hosting rock, distinguishing between burrows with remains that

991 were interpreted as belonging to the producer, those lacking bone remains and the present study.

992 Note that the age axis contains two gaps in the Cretaceous and Paleocene. Source of information

993 on Supplemental Article S1.

994

995 Figure 2. Study area in central Argentina (inset), outcrops of the Cerro Azul Formation and

996 localities in La Pampa and Buenos Aires provinces. LC: Laguna Chillhué, SG: Salinas Grandes

997 de Hidalgo, LLP: Laguna La Paraguaya. Modified from Cardonatto et al. (2016).

998

999 Figure 3. Location of landmarks (red points) on burrow fills preserved in cross section.

1000

1001 Figure 4. Detailed sedimentary logs of the measured sections.

1002 
1003 Figure 5. Abundance and cross-cutting relationships of burrows, from LLP locality. A) General

1004 view of the outcrop showing several burrows (yellow arrows). B-C) Field view and diagram of

1005 cross-cutting relationships between different fossil burrows (distinguished in $\mathrm{C}$ with different

1006 shades of gray).

1007

1008 Figure 6. Histogram showing the frequency distribution of horizontal diameter (Dh) for the 1009 studied fossil burrows. Three subpopulations can be distinguished.

1010

1011 Figure 7. Burrow morphology in plan view. A-B) Field photograph and diagram of slightly

1012 curved burrow. C-D) Field photograph and diagram of sinuous burrow. E-F) Field photograph

1013 and diagram of "C" shaped burrow. G-H) Field photograph and diagram of burrow with slightly

1014 enlarged and rounded end. Curved lines in the diagrams represent weathered laminae.

1015

1016 Figure 8. Results of geometric morphometric analysis of burrows observed in cross section. A)

1017 Plot of principal components 1 and 2, distinguishing by study locality, and deformation grids for

1018 elliptical (PC1 score -0.12) and subcircular (PC1 score 0.17) shapes. B) Histogram of variance of 1019 principal components.

1020

1021 Figure 9. Orientation of fossil burrows compared with modern data from dasypodid burrows. A)

1022 Rose diagram showing the dip azimuth of fossil burrow fills. B) Equal area projection of dip

1023 azimuth and dip angle of fossil burrows. C) Entrance orientation of fossil burrows, assuming that

1024 it is located at $180^{\circ}$ of measured dip azimuth. The data in A-C is from SG and LLP localities,

1025 those from the remaining locality are preserved only in cross-section. D) Entrance orientation of 
1026 several species of dasypodid burrows from semiarid settings of northern-central Argentina by

1027 Crespo (1944). E) Entrance orientation of Dasypus hibridus burrows from a grassland setting in

1028 Uruguay by González, Soutullo \& Altuna (2001). F) Entrance orientation of Chaetophractus

1029 villosus burrows from cultivated land in Buenos Aires province, Argentina by Abba, Udrizar \&

1030 Vizcaíno (2005).

1031

1032 Figure 10. Features of fossil burrow fills. A-B) Detailed sedimentary logs of the fill of selected

1033 burrows (see Table S1 for information on these burrow fills). References as for Fig. 4. C) Cross-

1034 section of laminated to massive burrow fill \# 648 from SG, represented in (B). Elliptical outline

1035 of fill indicated by yellow arrows, black arrow point to subvertical rhizolith cutting the laminated

1036 fill. D) Cross-section of burrow fill \# 714 from LLP. Subcircular outline of poorly laminated to

1037 massive burrow fill indicated by yellow arrows. E) Pseudomeniscate structure in burrow fill \#

1038704 from LLP seen in plan view. Yellow arrows point the outline of the burrow and black arrows

1039 to individual pseudomenisci. F) Detail of laminated burrow fill (\# 632 from SG) showing direct

1040 grading in siltstone to claystone laminae (yellow arrows), synsedimentary fault (white arrows)

1041 and onlap of clay laminae on burrow wall (black arrow).

1042

1043 Figure 11. Ichnofossils associated with burrow fills. A) Small burrow (black arrows) cutting the

1044 laminated fill of a larger mammal burrow (SG locality). B) Coprinisphaera isp. from LLP

1045 locality. C) Tetrapod footprints on the top of laminated fill of a burrow from LLP locality.

1046 Numbers refers to individual footprints. D) ?Rosellichnus isp. (arrowed) inside a burrow fill from

1047 SG.

1048 
1049 Figure 12. Bone remains inside burrow fills. A) Close-up of isolated, weathered and fragmentary 1050 glyptodontid osteoderms from a vertical section of a burrow fill from SG locality. The burrow

1051 boundary is not shown in the photograph. B) Partly articulated osteoderms of Eosclerocalyptus

1052 sp. found inside a burrow fill from LLP locality.

1053

\section{Legend of table}

1055 Table 1. Relationship between cross-sections and body mass of the putative producers, estimated 1056 body mass according to Wu et al. (2015). 


\section{Table $\mathbf{1}$ (on next page)}

Body mass estimate of producers.

Relationship between cross-sections and body mass of the putative producers, estimated body mass according to Wu et al. (2015). 
1 Table 1. Relationship between cross-sections and body mass of the putative producers, estimated

2 body mass according to $\mathrm{Wu}$ et al. (2015). Dh: horizontal diameter.

\begin{tabular}{|c|c|c|c|c|}
\hline $\begin{array}{l}\text { Range of } \\
\text { burrow Dh } \\
(\mathrm{m}) \\
\end{array}$ & $\begin{array}{c}\text { Estimaded } \\
\text { body mass } \\
(\mathrm{kg}) \\
\end{array}$ & $\begin{array}{l}\text { Fossil remains inside } \\
\text { burrow fill }\end{array}$ & $\begin{array}{l}\text { Potential burrow } \\
\text { producer }\end{array}$ & $\begin{array}{c}\text { Body mass of potential producer } \\
\text { (kg) }\end{array}$ \\
\hline $0.15-0.34$ & $1-13$ & Paedotherium minor & $\begin{array}{l}\text { Paedotherium } \\
\text { Doellotatus } \\
\text { Chasicotatus } \\
\text { Proeuphractus } \\
\text { Chorobates } \\
\text { Lagostomus }\end{array}$ & $\begin{array}{l}1.86 \text { (Elissamburu, 2004) } \\
\text { Less than } 1 \text { (Vizcaíno \& Fariña, 1999) } \\
\text { Less than } 1 \text { (Scillato -Yané et al., 2010) } \\
\text { 2-3 (Perea \& Scillato-Yané, 1995) } \\
1-10 \text { (Vizcaíno \& Fariña, 1999) } \\
1 \text { - } 10 \text { (Vizcaíno \& Fariña, 1999); }\end{array}$ \\
\hline $0.39-0.94$ & $37-439$ & $\begin{array}{l}\text { Mesotheriinae indet. } \\
\text { Eosclerocalyptus sp. } \\
\text { Gliptodontidae indet. } \\
\text { Gliptodontidae indet. }\end{array}$ & $\begin{array}{l}\text { Mesotheriinae } \\
\text { Eosclerocalyptus } \\
\text { Coscinocercus } \\
\text { Aspidocalyptus } \\
\text { Macrochorobates } \\
\text { Macroeuphractus } \\
\text { Proscelidodon }\end{array}$ & $\begin{array}{l}20.88 \text { - } 60.13 \text { (Croft, Flynn \& Wyss,, 2004) } \\
\text { More than } 100 \text { (Vizcaíno \& Fariña, 1999) } \\
\text { More than } 100 \text { (Vizcaíno \& Fariña, 1999) } \\
\text { More than } 100 \text { (Vizcaíno \& Fariña, 1999) } \\
10-100 \text { (Vizcaíno \& Fariña, 1999) } \\
10-100 \text { (Vizcaíno \& Fariña, 1999) } \\
581.8 \text { (De Esteban-Trivigno, Mendoza \& } \\
\text { De Renzi,, 2008); } 850 \text { (Bargo et al., 2000); } \\
\text { 1057 (Fariña, Vizcaíno \& Bargo, 1998). } \\
\text { Body mass of S.leptocephalum }\end{array}$ \\
\hline & & $\begin{array}{l}\text { Paedotherium minor } \\
\text { Doellotatus sp. }\end{array}$ & Doellotatus & \\
\hline $1.05-1.5$ & $\begin{array}{l}708- \\
1623\end{array}$ & Gliptodontidae indet. & $\begin{array}{l}\text { Glyptodontidae } \\
\text { Proscelidodon }\end{array}$ & $\begin{array}{l}\text { More than } 100 \text { (Vizcaíno \& Fariña, 1999) } \\
\text { 581.8 (De Esteban-Trivigno, Mendoza \& } \\
\text { De Renzi,, 2008); } 850 \text { (Bargo et al., } \\
\text { 2000);1057 (Fariña, Vizcaíno \& Bargo, } \\
\text { 1998). Body mass of S. leptocephalum. }\end{array}$ \\
\hline
\end{tabular}




\section{Figure 1}

Plot of horizontal diameter of fossil tetrapod burrows vs age

Plot of the average horizontal diameter (Dh) of fossil tetrapod burrows in the published literature against the age of the hosting rock, distinguishing between burrows with remains that were interpreted as belonging to the producer, those lacking bone remains and the present study. Note that the age axis contains two gaps in the Cretaceous and Paleocene. Source of information on Supplemental Article S1. Image credit: Ricardo N. Melchor and María C. Cardonatto 


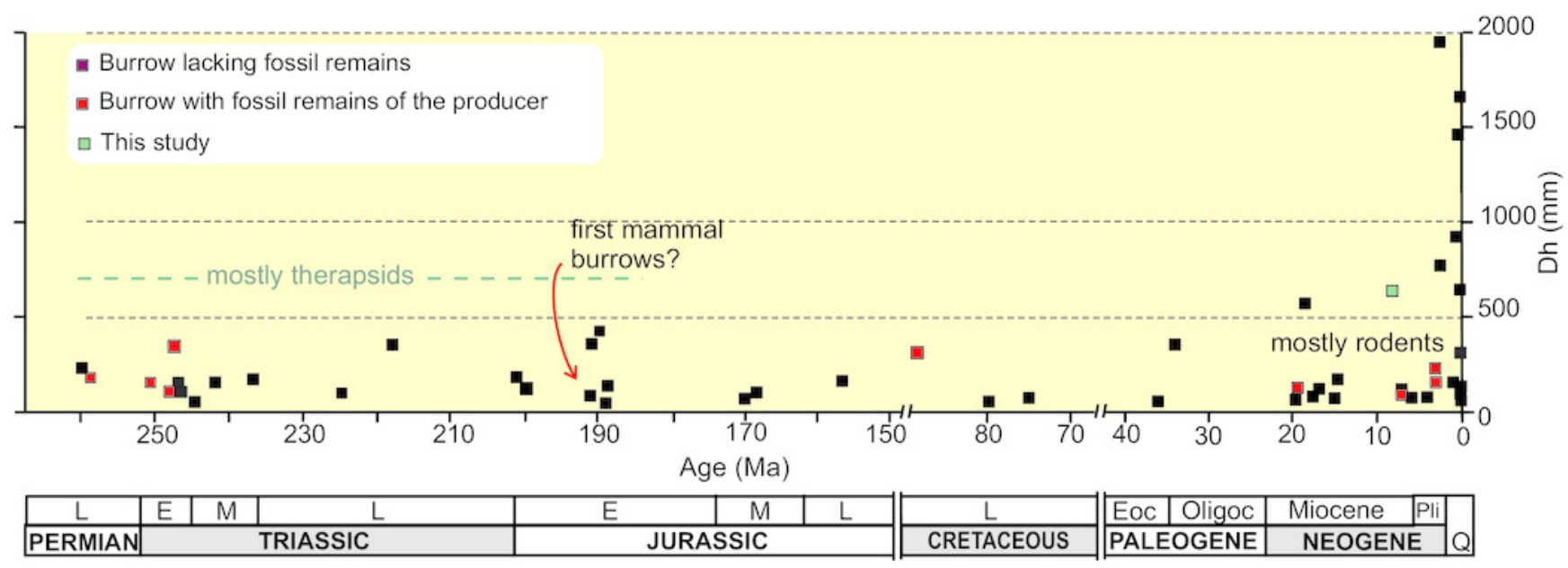




\section{Figure 2}

Study area.

Study area in central Argentina (inset), outcrops of the Cerro Azul Formation and localities in La Pampa and Buenos Aires provinces. LC: Laguna Chillhué, SG: Salinas Grandes de Hidalgo, LLP: Laguna La Paraguaya. Modified from Cardonatto et al. (2016). 


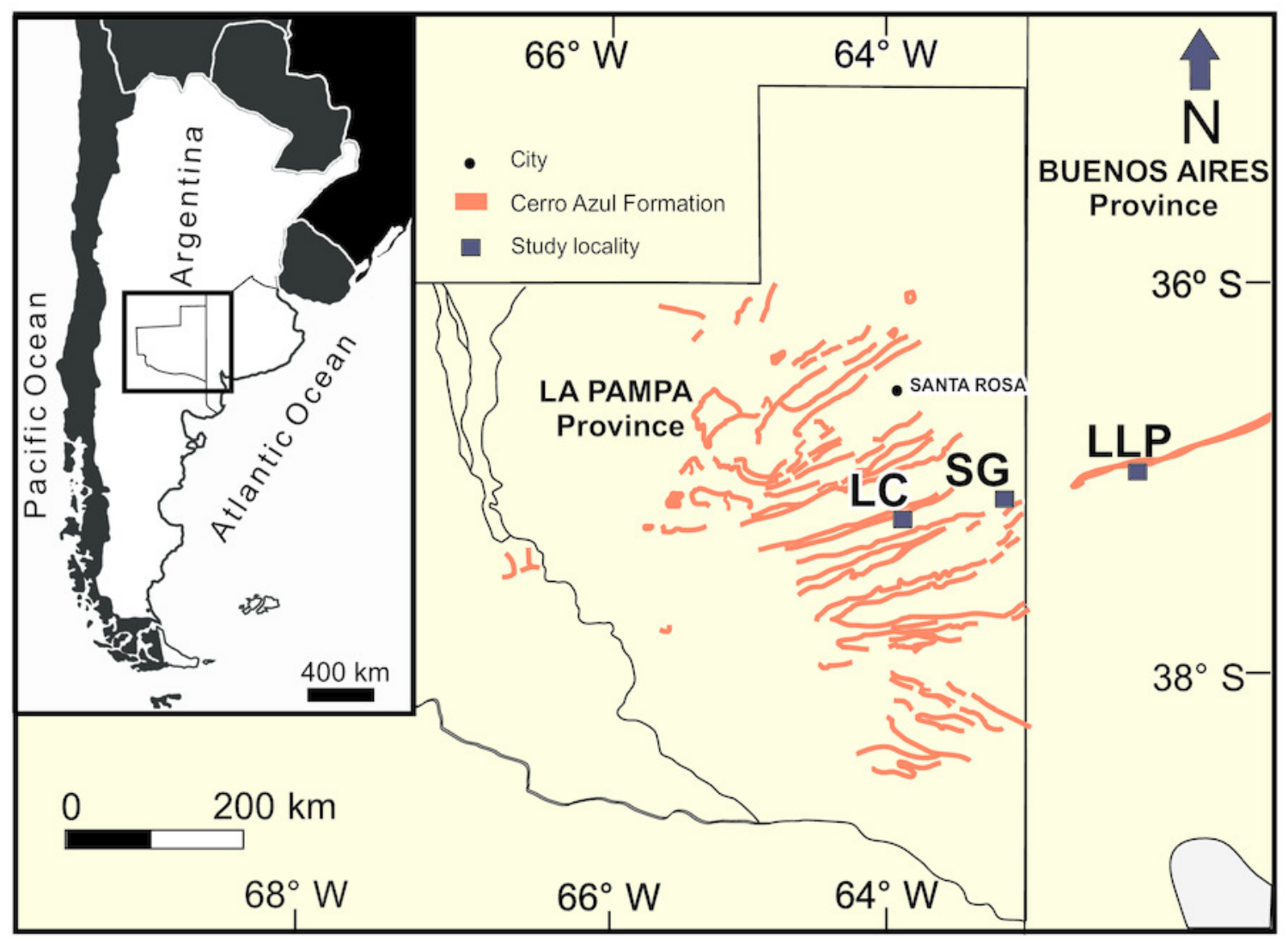


Figure 3

Example of location of landmarks.

Location of landmarks (red points) on burrow fills preserved in cross section. Photo credit: Ricardo Néstor Melchor.

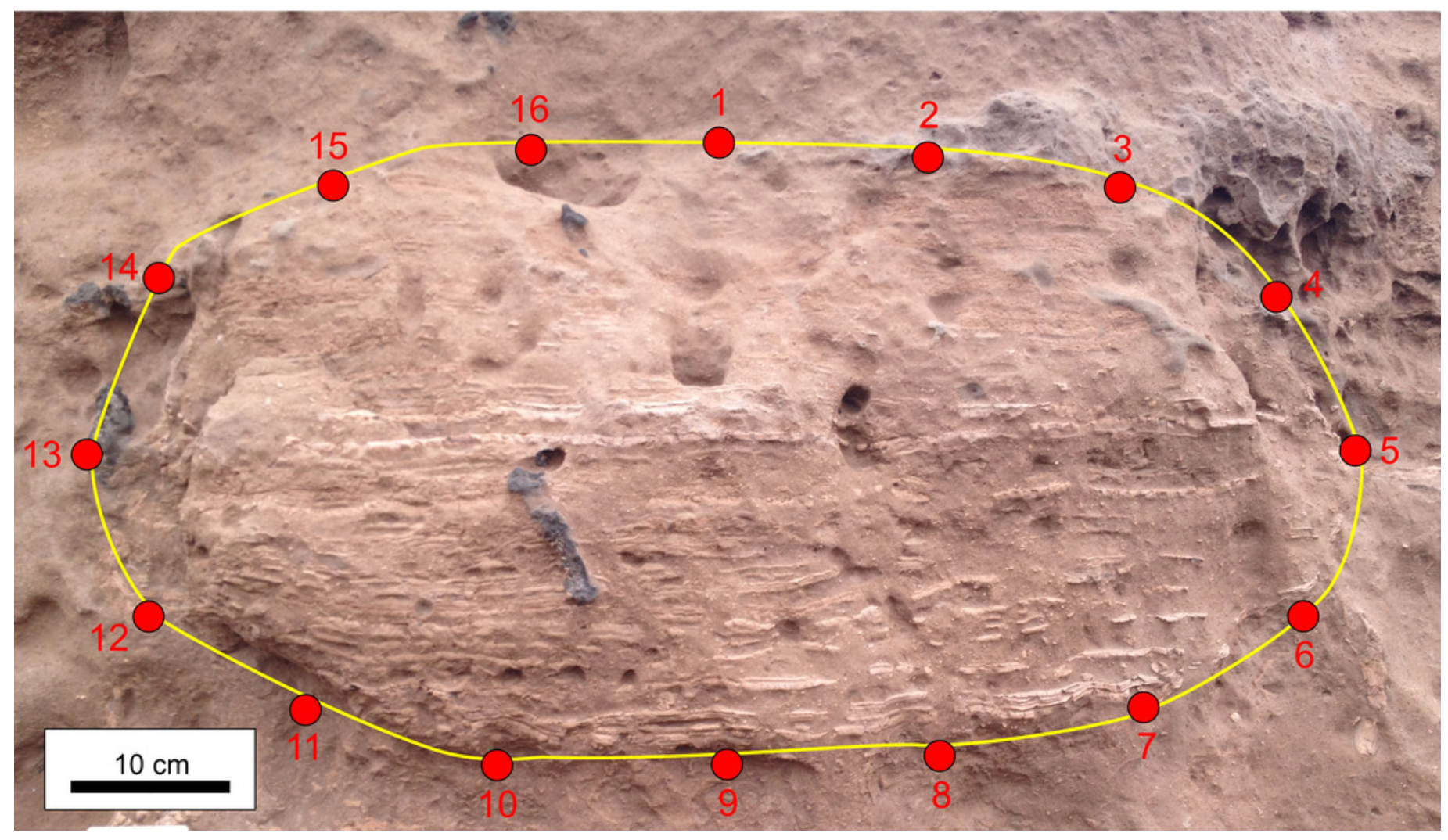


Figure 4

Sedimentary logs.

Detailed sedimentary logs of the measured sections from the study localities. Image credit:

Ricardo Néstor Melchor. 

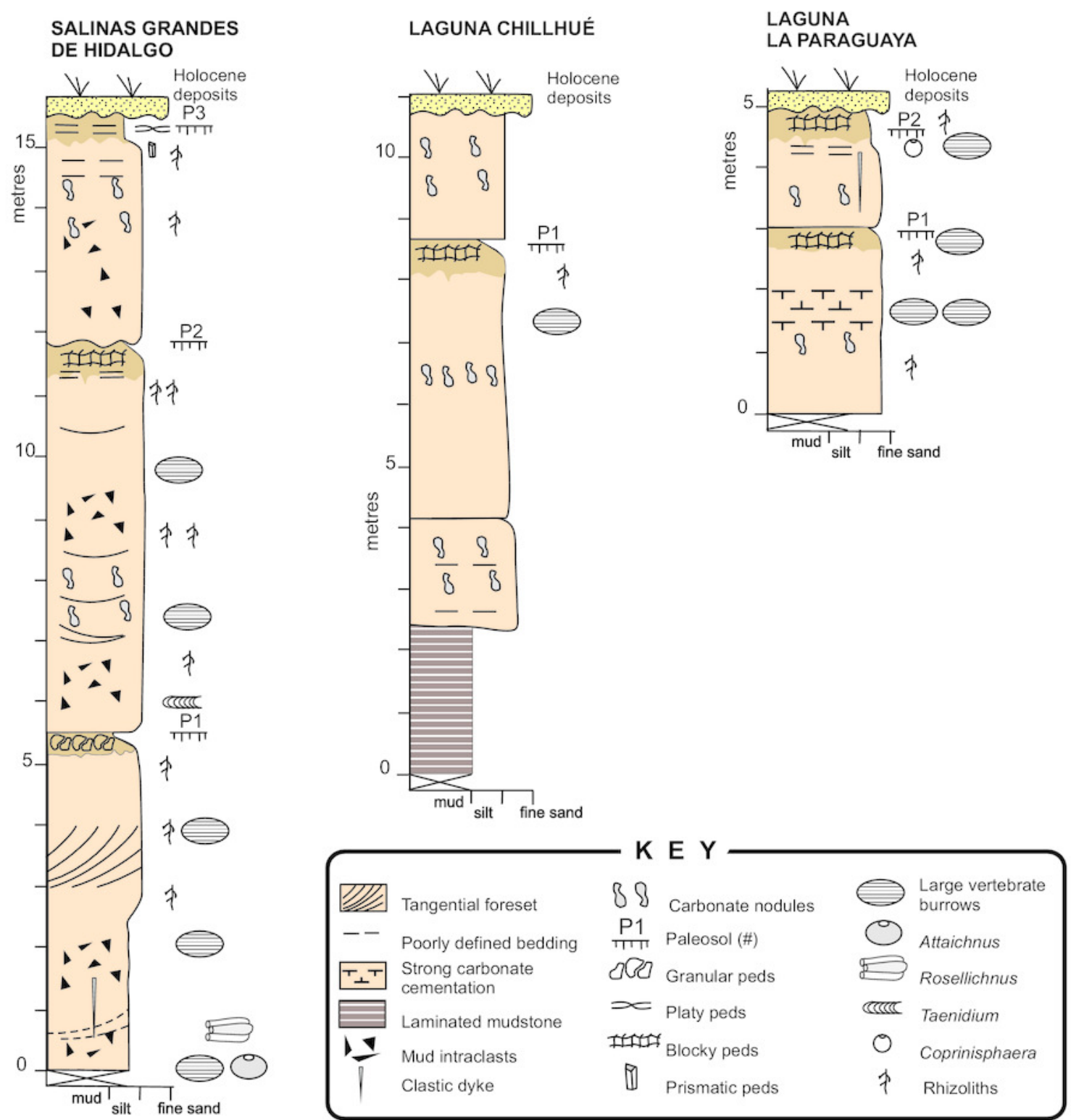


\section{Figure 5}

Cross-cutting relationships of fossil burrows.

(A) Abundance and cross-cutting relationships of burrows, from LLP locality. A) General view of the outcrop showing several burrows (yellow arrows). (B-C) Field view and diagram of cross-cutting relationships between different fossil burrows (distinguished in $\mathrm{C}$ with different shades of gray). Photo and image credit: Ricardo Néstor Melchor. 

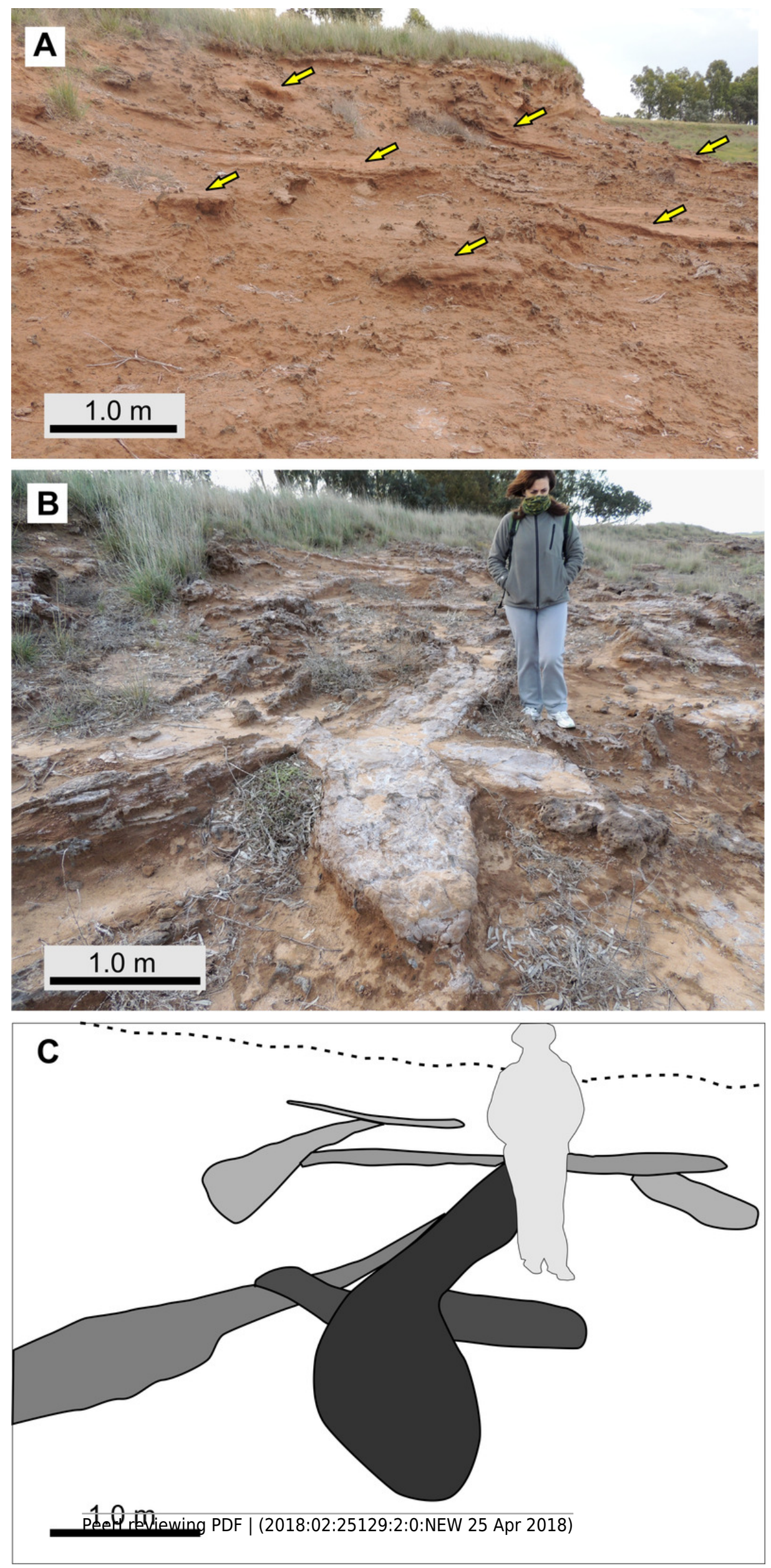


\section{Figure 6}

Histogram of horizontal diameter.

Histogram showing the frequency distribution of horizontal diameter (Dh) for the studied fossil burrows. Three subpopulations can be distinguished. Image credit: María Cristina Cardonatto.

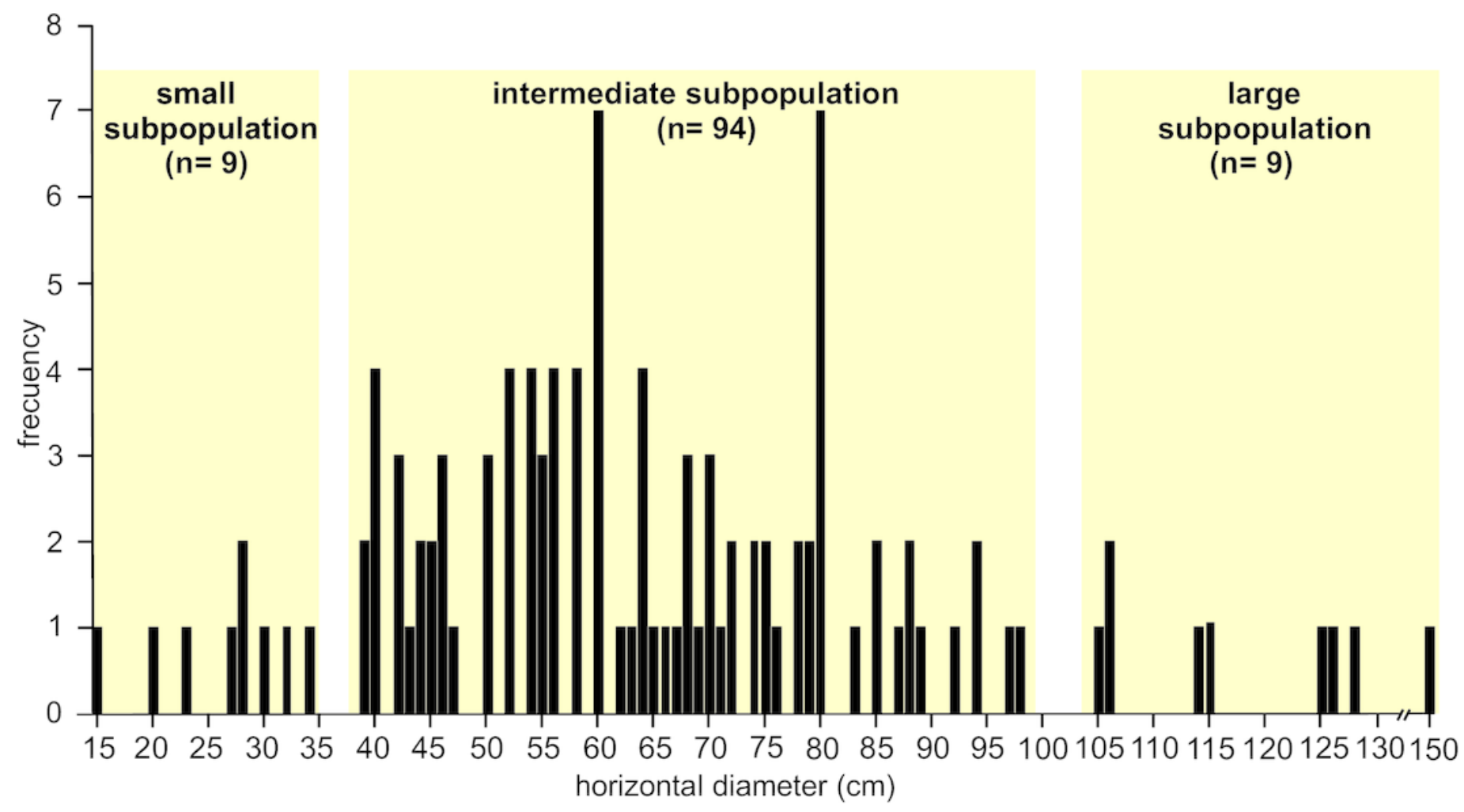




\section{Figure 7}

Burrow morphology in plan view.

(A-B) Field photograph and diagram of slightly curved burrow. (C-D) Field photograph and diagram of sinuous burrow. (E-F) Field photograph and diagram of " $\mathrm{C}$ " shaped burrow. (G-H) Field photograph and diagram of burrow with slightly enlarged and rounded end. Curved lines in the diagrams represent weathered laminae. Photo credit: Ricardo Néstor Melchor. Image credit: María Cristina Cardonatto. 

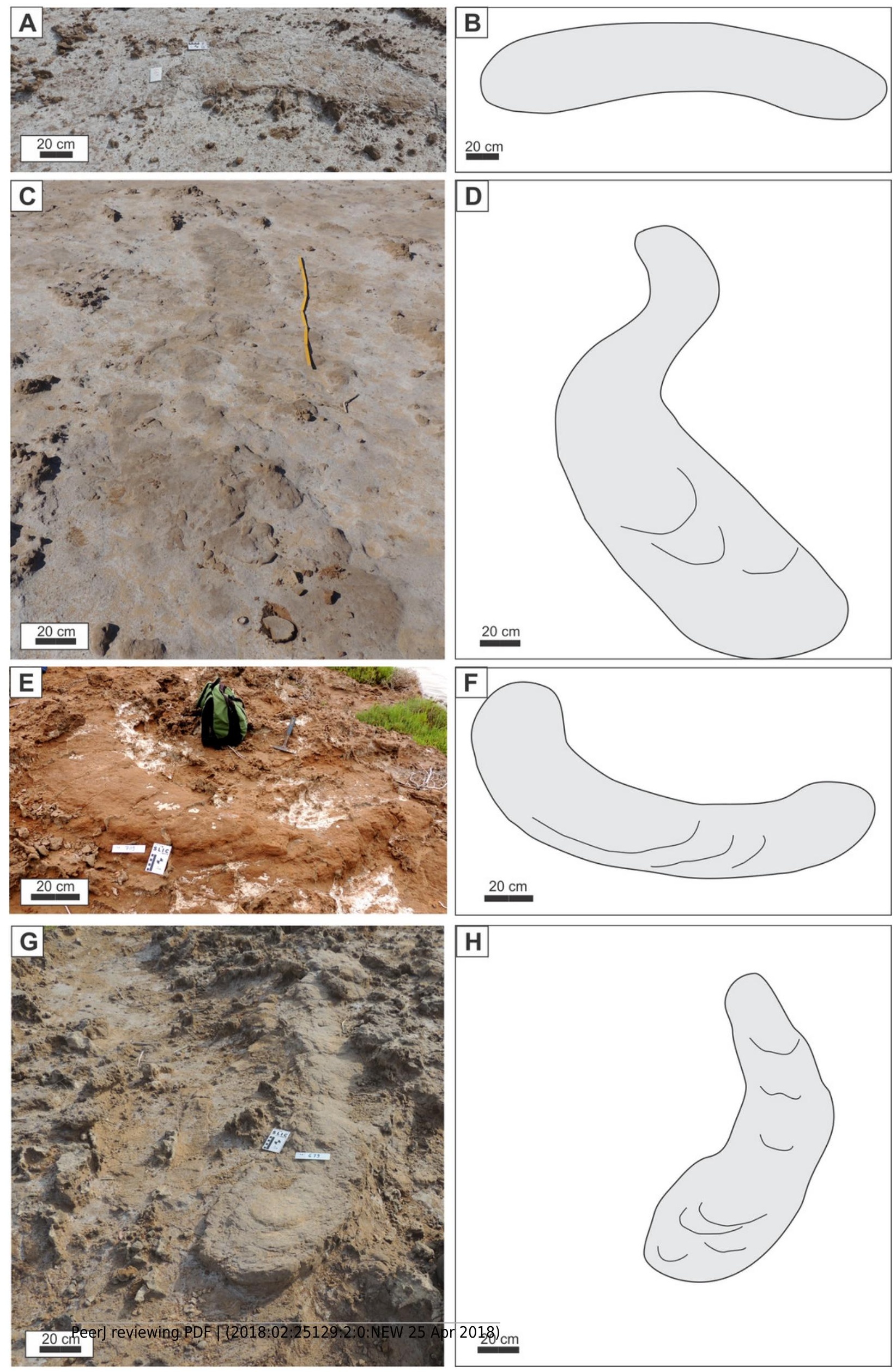


\section{Figure 8}

Results of geometric morphometric analysis of fossil burrows preserved in cross section.

(A) Plot of principal components 1 and 2, distinguishing by study locality, and deformation grids for elliptical (PC1 score -0.12) and subcircular (PC1 score 0.17) shapes. (B) Histogram of variance of principal components. Image credit: María Cristina Cardonatto. 
A
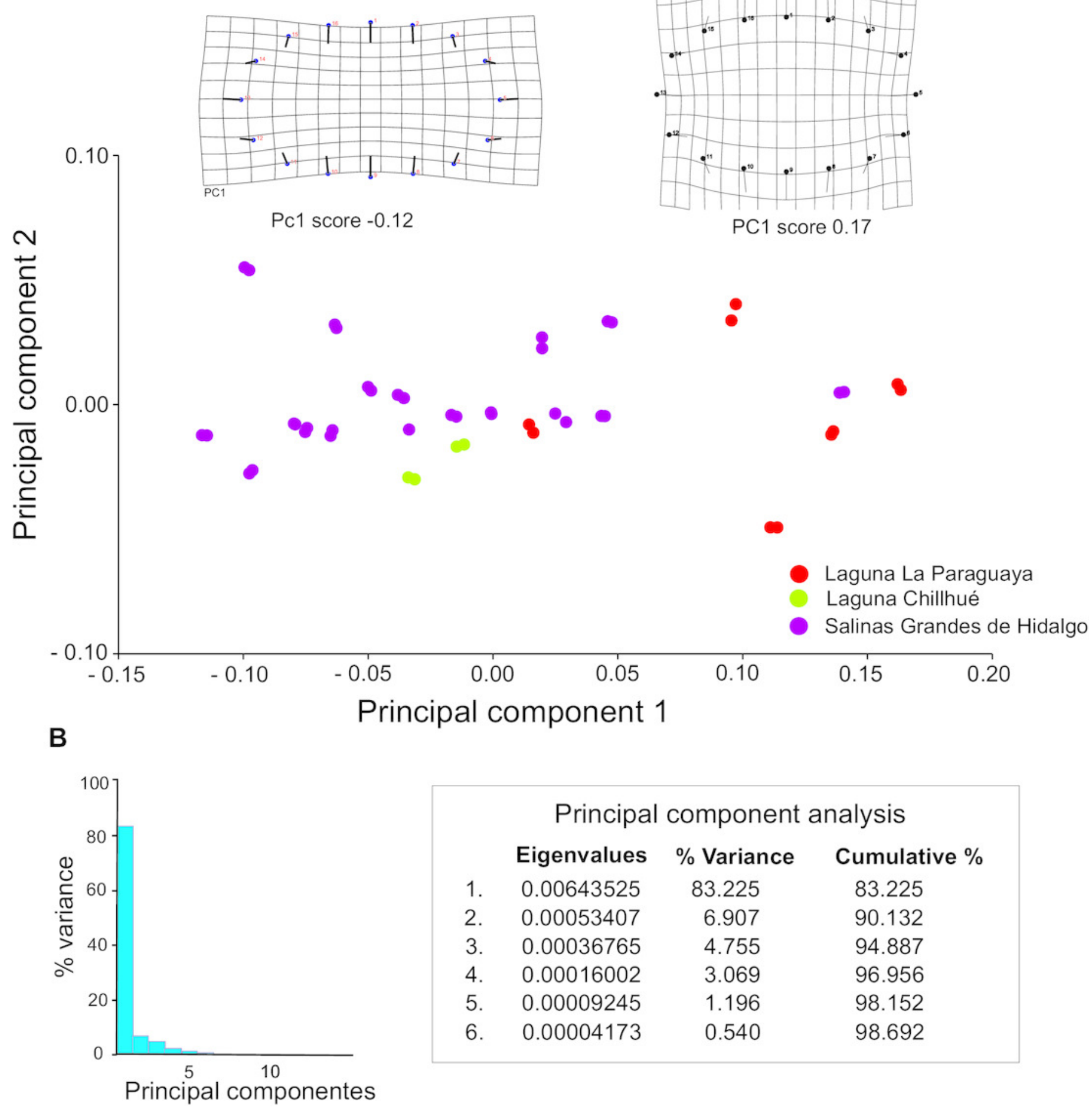

Principal component analysis

Eigenvalues \% Variance Cumulative \%

1. $0.00643525 \quad 83.225 \quad 83.225$

2. $0.00053407 \quad 6.907 \quad 90.132$

$\begin{array}{llll}\text { 3. } & 0.00036765 & 4.755 & 94.887\end{array}$

4. $0.00016002 \quad 3.069 \quad 96.956$

5. $0.00009245 \quad 1.196 \quad 98.152$

$\begin{array}{llll}\text { 6. } & 0.00004173 & 0.540 & 98.692\end{array}$ 


\section{Figure 9}

Orientation of fossil burrows compared with modern data from dasypodid burrows.

(A) Rose diagram showing the dip azimuth of fossil burrows. (B) Equal area projection of dip azimuth and dip angle of fossil burrows. (C) Entrance orientation of fossil burrows, assuming that it is located at $180^{\circ}$ of measured dip azimuth. The data in A-C is from SG and LLP localities, those from the remaining locality are preserved only in cross-section. (D) Entrance orientation of several species of dasypodid burrows from semiarid settings of northerncentral Argentina build from data by Crespo (1944). (E) Entrance orientation of Dasypus hibridus burrows from a grassland setting in Uruguay build from data by González et al. (2001). (F) Entrance orientation of Chaetophractus villosus burrows from cultivated land in Buenos Aires province, Argentina build from data by Abba et al. (2005). Image credit: Ricardo Néstor Melchor. 
A
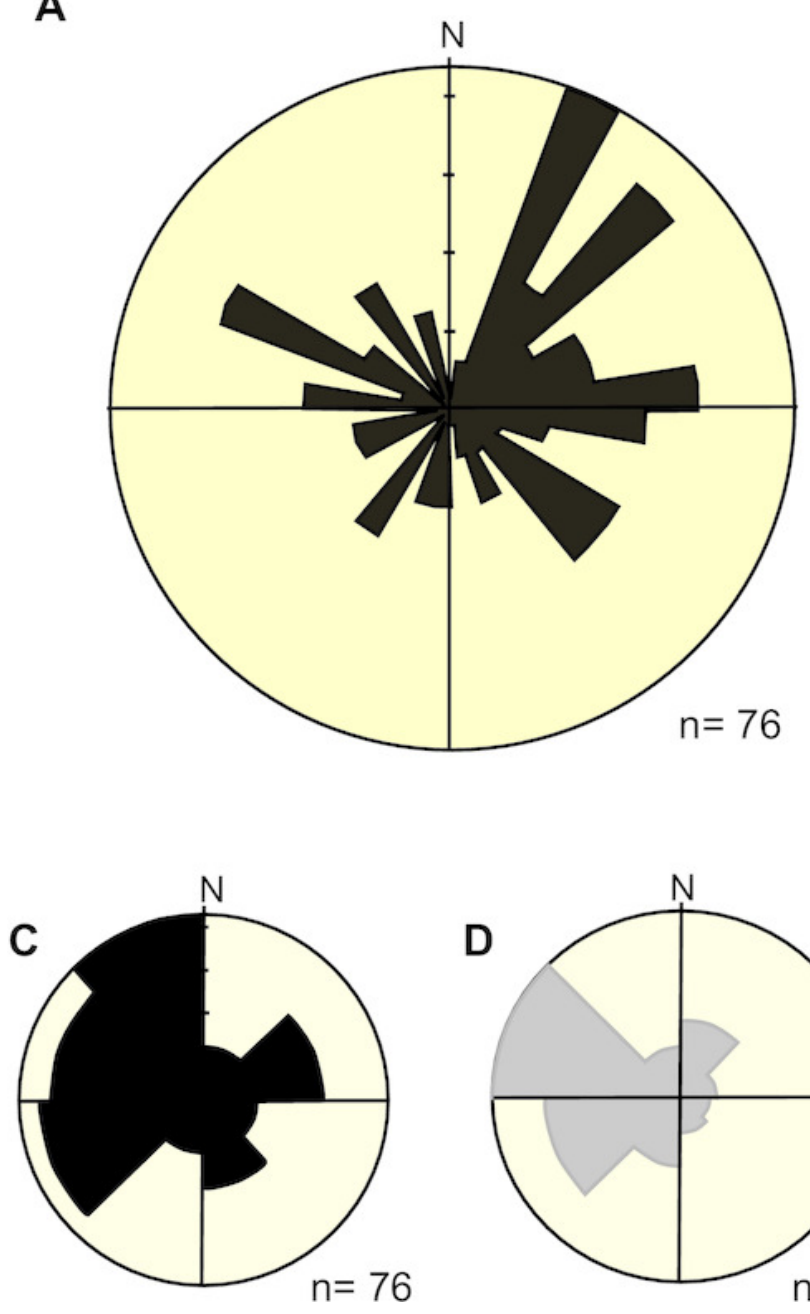

D

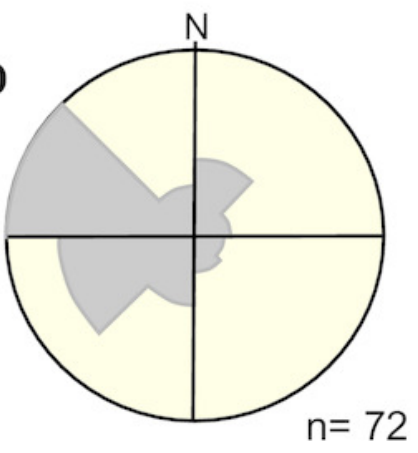

B

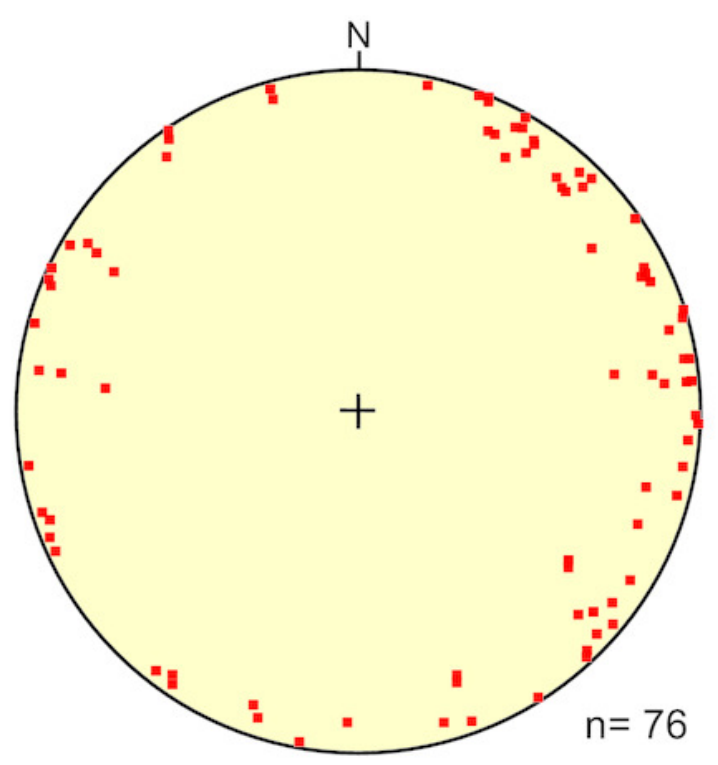

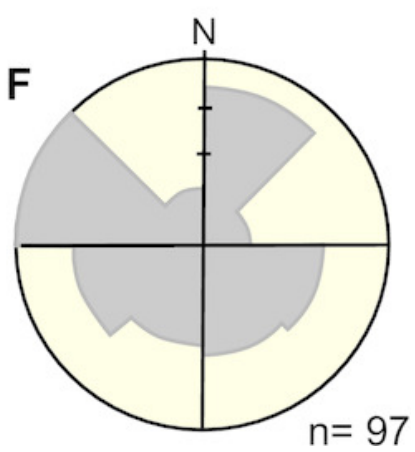




\section{Figure 10}

Features of fossil burrow fills.

(A-B) Detailed sedimentary logs of the fill of selected burrows (see Table S1 for information on these burrow fills). References as for Fig. 4. (C) Cross-section of laminated to massive burrow fill \# 648 from SG, represented in (B). Elliptical outline of fill indicated by yellow arrows, black arrow point to subvertical rhizolith cutting the laminated fill. (D) Cross-section of burrow fill \# 714 from LLP. Subcircular outline of poorly laminated to massive burrow fill indicated by yellow arrows. (E) Pseudomeniscate structure in burrow fill \# 704 from LLP seen in plan view. Yellow arrows point the outline of the burrow and black arrows to individual pseudomenisci. (F) Detail of laminated burrow fill (\# 632 from SG) showing direct grading in siltstone to claystone laminae (yellow arrows), synsedimentary fault (white arrows) and onlap of clay laminae on burrow wall (black arrow). Image credit: Ricardo Néstor Melchor. 

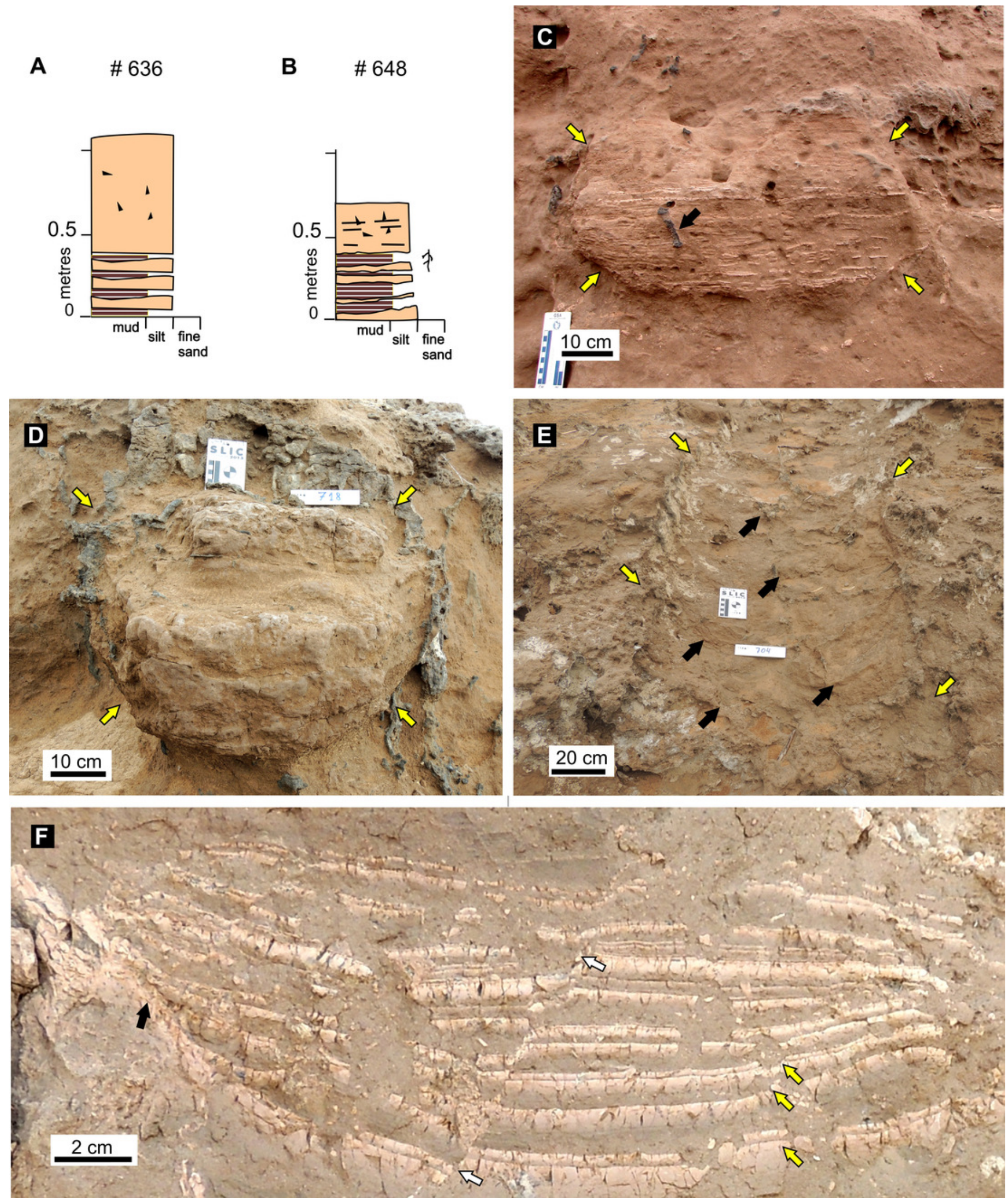


\section{Figure 11}

Ichnofossils associated with burrow fills.

(A) Small burrow fill (black arrows) cutting the laminated fill of a larger mammal burrow from SG locality. (B) Coprinisphaera isp. from LLP locality. (C) Tetrapod footprints on the top of laminated fill of a burrow from LLP locality. Numbers refers to individual footprints. (D) ?Rosellichnus isp. (arrowed) inside a burrow fill from SG. Photo credit: Ricardo Néstor Melchor.
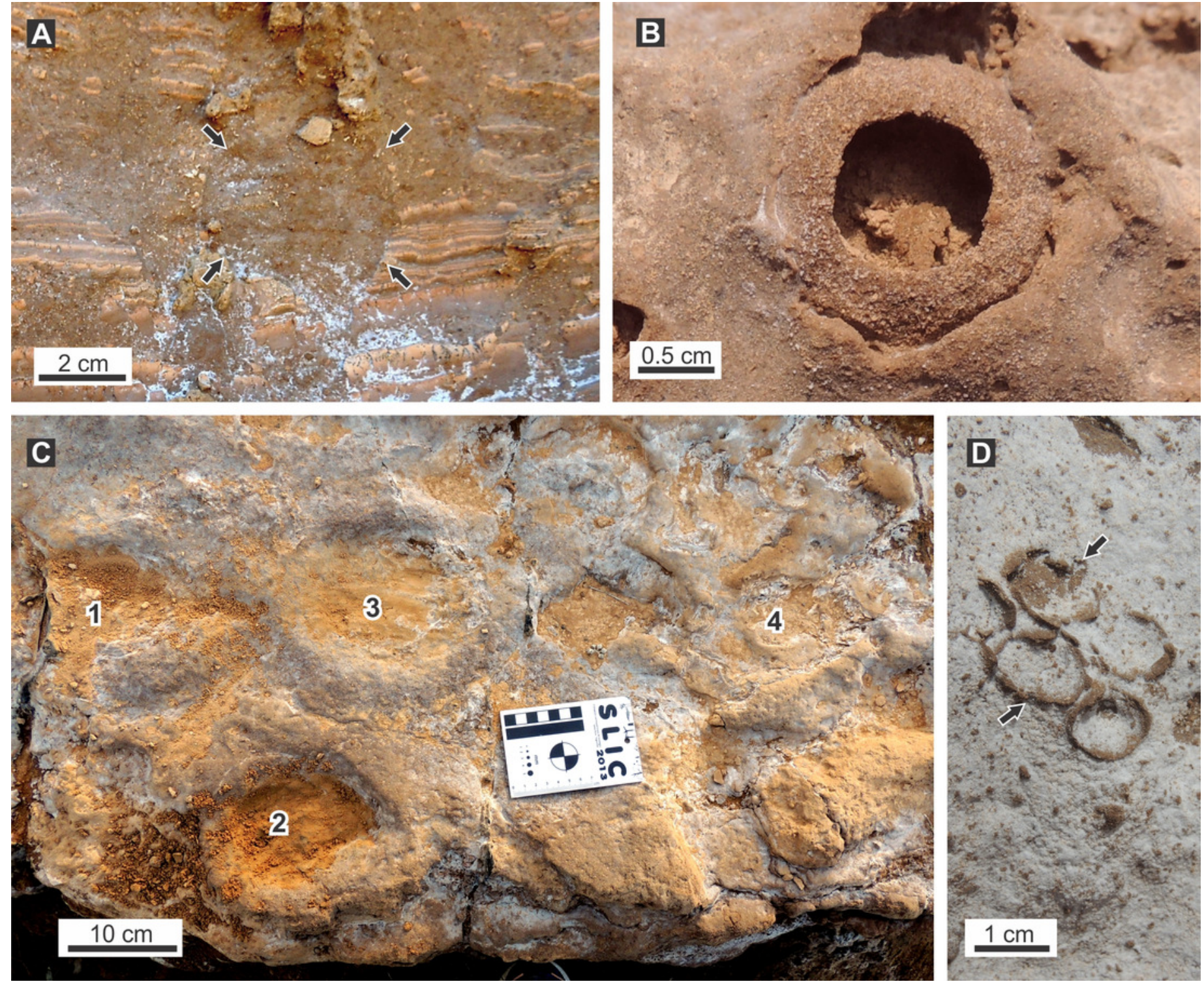


\section{Figure 12}

Bone remains inside burrow fills.

(A) Close-up of isolated, weathered and fragmentary glyptodontid osteoderms from a vertical section of a burrow fill from SG locality. The burrow boundary is not shown in the photograph.

(B) Partly articulated osteoderms of Eosclerocalyptus sp. found inside a burrow fill from LLP locality. Photo credit: Ricardo Néstor Melchor.
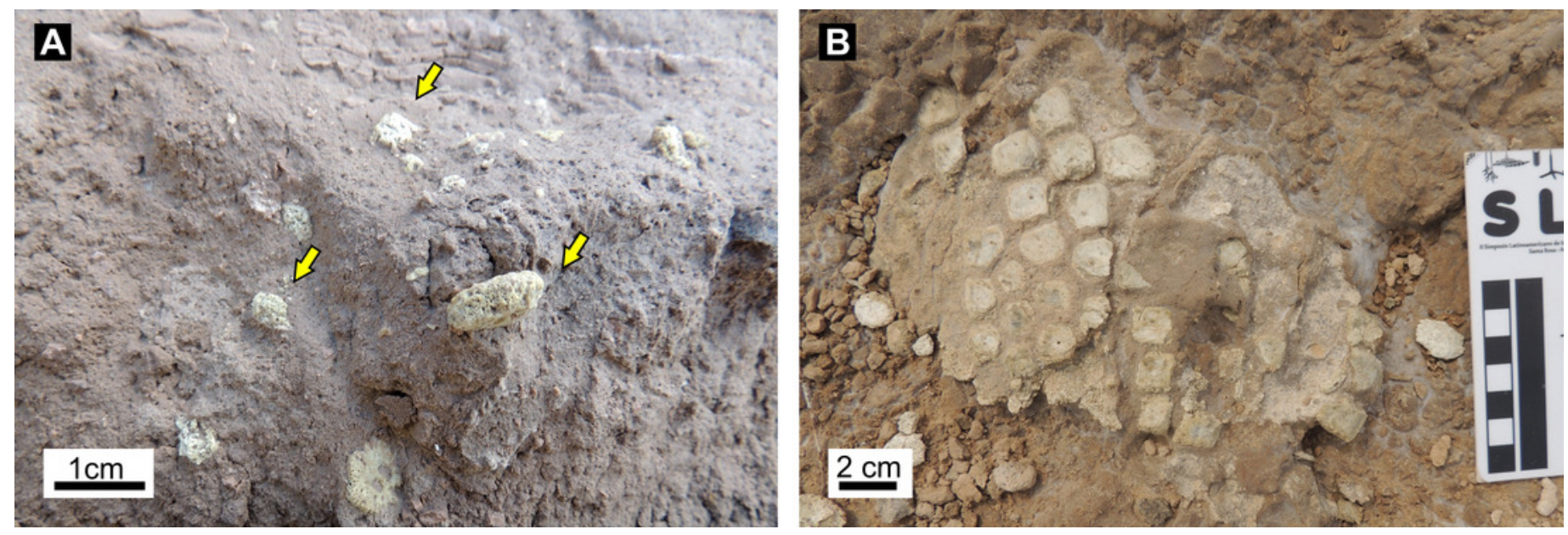